
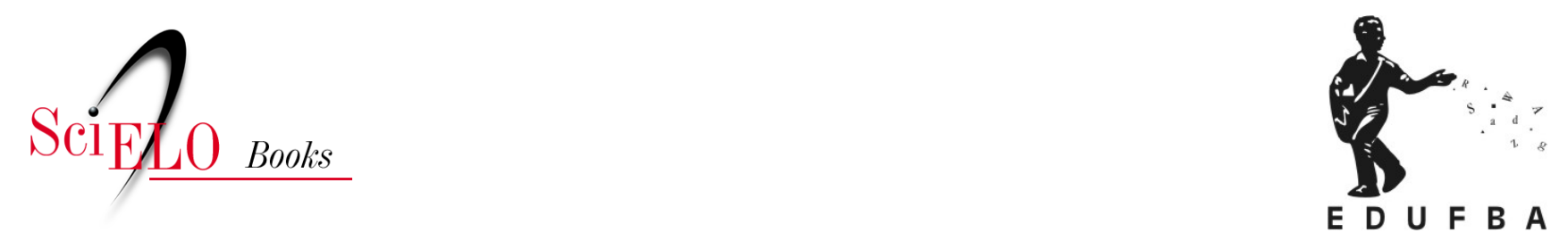

\title{
4 - Evolução e consolidação da política nacional de luta contra a aids (1990-2001)
}

\author{
Sandra Garrido de Barros
}

\section{SciELO Books / SciELO Livros / SciELO Libros}

BARROS, S.G. Evolução e consolidação da política nacional de luta contra a aids (1990-2001). In: Política Nacional de Aids: construção da resposta governamental à epidemia HIV/aids no Brasil [online]. Salvador: EDUFBA, 2018, pp. 122-189. ISBN 978-85-232-2030-3. https://doi.org/10.7476/9788523220303.0005.

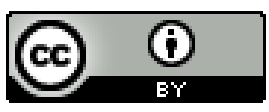

All the contents of this work, except where otherwise noted, is licensed under a Creative Commons Attribution 4.0 International license.

Todo o conteúdo deste trabalho, exceto quando houver ressalva, é publicado sob a licença Creative Commons Atribição 4.0. 



\section{4 \\ Evolução e consolidação \\ da política nacional de luta contra a aids (1990-2001)}

A resposta à epidemia da aids, na década de 1980, ocorreu a partir da integração e complementaridade da ação de agentes de diferentes subespaços. Sendo os homossexuais o principal grupo afetado àquele momento pela aids, o movimento gay teve importante papel na divulgação de informações acerca da doença e sua prevenção, assim como demandou uma resposta governamental. A ocorrência de casos concentrava-se na maior cidade e principal centro econômico do país, a cidade de São Paulo, onde também surgiu, no final da década de 1970, o primeiro grupo homossexual do Brasil: o grupo Somos, a partir do qual o referido movimento se organizou no país. Apesar de em um primeiro momento o movimento gay ter negado a doença, teve papel fundamental no reconhecimento da aids como um problema social que necessitava de medidas específicas.

A resposta governamental à aids, no Brasil, apresentou uma especificidade, relacionada ao nível de governo que implantou as primeiras ações. Tradicionalmente o Ministério da Saúde formulava uma política nacional que era seguida e operacionalizada pelas unidades federativas. Em relação à aids, diversas ações começaram a ser implementadas nos estados, mesmo quando o Ministério da Saúde ainda não tinha proposições para atuação frente a nova doença e até mesmo negava a necessidade de intervenção. A SES-SP foi pioneira ao implantar o seu Programa de DST/ Aids no segundo semestre de 1983, sendo seguida por outros governos estaduais como Rio de Janeiro e Rio Grande do Sul. A política nacional de combate à epidemia começou a ser implantada em 1985, ano de preparação para a $8^{\text {a }}$ Conferência Nacional de Saúde, quando o movimento 
da reforma sanitária começava a debater nacionalmente seu projeto, e também ano da eleição de Tancredo Neves, com diversos quadros do movimento, assumindo postos nas secretarias estaduais de saúde desde 1983 e no Ministério da Saúde a partir de 1985, e quando ainda eram incipientes as possibilidades terapêuticas com relação à aids.

Foi a partir da década de 1990, com a efetiva definição de dispositivos legais para a implantação do SUS e novas alternativas de medicamentos antirretrovirais, ${ }^{78}$ bem como com a garantia de recursos financeiros através do acordo de empréstimo junto ao Banco Mundial que a política nacional de aids se consolidou. Este capítulo trata do período de 1990 a 2001, abordando a fase de consolidação da política (1990-1996) e de conformação de estratégias para a sustentabilidade da garantia do acesso universal (1997-2001).

\section{Retrocessos e avanços do governo Collor}

A década de 1990 iniciou com o primeiro governo federal eleito de forma direta através do voto popular após o período da ditadura militar: o governo Collor. Marcado pela política neoliberal de redução do Estado, embasada numa reforma econômica e administrativa com importante corte de gastos públicos, o que implicou em grandes entraves para o avanço da Reforma Sanitária e do Sistema Único de Saúde. (FALEIROS et al., 2006) Ainda que tenham sido promulgadas as Leis Orgânicas da Saúde (Lei 8.080/90 e Lei 8.142/90), a publicação da Norma Operacional Básica - NOB o1/91 subverteu diversas conquistas dessas leis. Os retrocessos políticos levaram a uma desmobilização do movimento sanitário, dando espaço para um maior protagonismo dos gestores municipais e estaduais. Ao mesmo tempo, se a legislação ampliou o acesso da população

O AZT (zidovudina) foi registrado no FDA em março de 1987; o ddl (didanosina) em 1991; o ddC (zalcitabina) em 1992; o d4T (estavudina) em 1994; O 3 TC (lamivudina) e o SQV (saquinavir) em 1995; o RTV (ritonavir), o IDV (indinavir) e oNVP (nevirapina) em 1996; o NFV (nelfinavir), DLV (delavirdina) e o AZT+3TC em 1997; o EFV(efavirenz) e o ABV (abacavir) em 1998; APV (amprenavir) em 1999; o LPV (lopinavir+ritonavir), o ddiE (didanosina entérica e o ABV+AZT+3TC em 2000; e o TNV (tenofovir) em 2001. 
aos serviços públicos de saúde, houve uma redução da ordem de cerca de $50 \%$ dos recursos destinados à saúde. (PAIM, 2008)

Foi nessa conjuntura que Alceni Guerra ${ }^{79}$ assumiu o Ministério da Saúde, nomeando para Secretário Nacional de Assistência à Saúde Ricardo Ackel, ${ }^{80}$ que convidou para assumir a Divisão Nacional de Aids o médico Eduardo Jorge Bastos Côrtes, professor da UFRJ desde 1977, instituição na qual se formou e fez Residência em Terapia Intensiva, com mestrado em Oncologia pela Universidade da Califórnia (UCLA), um dos principais centros de estudo de aids do mundo, onde estudou as neoplasias da aids. Côrtes havia retornado dos EUA expressando uma posição de oposição à política nacional, com algum destaque na imprensa. Na sua opinião, a estratégia governamental menosprezava a expansão e a heterossexualização da epidemia, bem como a identificação do HIV-2 no país e a necessidade de implementar ações de prevenção e tratamento. (“AFRICANIZAÇÃO”..., 1988; CÔRTES..., 1988; OPERÁRIOS..., 1988) Alceni pretendia manter Côrtes sob "rédeas curtas", pois considerava que Lair Guerra tinha “autonomia excessiva”. (RÉDEAS..., 1990, p. A-4)

A forma como foi conduzida a troca de dirigentes, com Lair Guerra recebendo a notícia da sua exoneração pelos jornais, causou constrangimento na equipe ${ }^{81}$ levando ao afastamento voluntário de quase todos seus integrantes. (E15; E27)

79 Médico formado pelo UFPR (1972), com Pós-Graduação em Pediatria também pela UFPR (1973-1974), Chefe do Serviço de Medicina Social do Inamps da agência da Previdência Social em Pato Branco (1976-1979), Superintendente Regional do Instituto de Assistência Médica da Previdência Social do Estado do Paraná (1979-1982), elegeu-se Deputado Federal em 1983-1987 pelo PDS-PR e em 1987-1991 pelo PFL-PR; e Prefeito do Município de Pato Branco-PR, 19972000, também pelo PFL. Ministro de Estado de Saúde, 1990-1992, durante o governo Collor.

80 Médico, Professor Assistente da UFPR (17/06/1980-20/11/1997), Diretor do Hospital de Clínicas da UFPR (1986-1990), Presidente do Inamps e Secretário Nacional de Assistência à Saúde, durante o governo Collor de Melo (1990-1992).

81 [...] muita gente saiu, acho que foi mais por questão de fidelidade, como tudo se processou. Porque eu trabalhei diretamente com a Dra. Lair desde a criação. Ela fica sabendo que não é mais diretora por um jornal do Rio de Janeiro. [...] Ela ficou sabendo por alguém do Rio de Janeiro que ligou pra ela e disse: 'Olha, quem vaiser o novo coordenador éo Eduardo Côrtes.' [...] a gente achou que não foi uma maneira política e correta de se exonerar uma pessoa que se dedicou a essa luta, brigou pela luta. [...] eu não ia me sentir a vontade com uma pessoa que eu não conhecia, teve seus méritos claro, mas eu não conhecia. Então, como eu era do 
[...] as pessoas ficaram com medo de serem demitidas. Então todo mundo se ajeitou. Como gente saiu de outros lugares e veio também. Então, eu recebi aquilo realmente arrasado, porque de quarenta e poucas pessoas, ficaram lá, quatro. E [devido] a reforma administrativa, eu só ia poder ter uma secretária, que era no organograma das divisões que foi uma briga grande que eu tive lá, uma secretária e dois assessores. Eu tinha três DAS pra dar. [...] eu fiquei inicialmente com menos de 10 pessoas. (E7)

Além da conjuntura de reforma administrativa, a mudança de governo também implicou em uma descontinuidade para a política de aids, não apenas relacionada à entrada de um novo gestor e aos cortes de recursos do setor saúde, mas devido ao esvaziamento da equipe, a perda do status de prioridade, ${ }^{82}$ além do acesso limitado do novo gestor do programa ao ministro, pelo menos até o início do segundo semestre de 1991, quando a situação do programa foi apresentada ao ministro em uma reunião.

O Alceni Guerra incluiu a aids dentro das prioridades do ministério depois da famosa reunião que eu disse em público que o Programa de aids estava aquém das necessidades para o controle da epidemia no Brasil. Foi uma reunião fechada, mas pública, com todo Estado maior e Estado menor. Na hora que eu fuifazer o meu relato, eu tive a coragem de dizer isso pra ele. E ele ficou danado da vida, interrompeu a reunião e saiu. No dia seguinte ele recomeçou a reunião e ele não me demitiu. Ele até valorizou isso e incluiu a aids na reunião estratégica que ele tinha às segundasfeiras [...]. Foi quando teve a grande mudança da aids no Brasil, que eu já tinha ido ao Banco Mundial e ele incluiu a aids e a agente acertou tudo. (E7)

Eduardo Côrtes, um jovem pesquisador que estudava a soroprevalência em populações vulneráveis à infecção pelo HIV, foi visto inicialmente como uma possibilidade de revitalização do Programa Nacional cuja gestão anterior era criticada pelo tecnicismo e centralização. (PARKER, 2003)

quadro do ministério, preferi me ausentar esse momento até para não atrapalhar o trabalho dele aqui e deixar ele mais a vontade pra montar a equipe dele como ele quisesse. (E15)

82 [...] antes, como eu te disse, não era prioridade. Na semana que eu entreiteve uma entrevista do Alceni Guerra, no Rio, que ele veio pedir à Xuxa, que na época estava no auge, pra fazer parte na campanha de crianças, né? De diarreias, desnutrição infantil e tal. Ea imprensa sempre perguntando sobre aids. Ele falou assim "Que aids? Aids não é um problema. Problema é diarreia e mortalidade infantil'. (E7) 
Contudo, sem conseguir se articular com os pesquisadores da Fiocruz, dominantes no campo científico, e com a oposição das ONGs em reação à campanha veiculada em $1991,{ }^{83}$ mesmo com bons relacionamentos nos EUA, Côrtes permaneceu isolado. Ou seja, se no espaço aids norte-americano ele relacionava-se com o pólo dominante ligado à oncologia, no Brasil seu capital científico, no interior do espaço aids, era restrito. A oncologia, sua especialidade de origem, não teve papel preponderante na resposta à epidemia da aids no Brasil, como teve nos EUA. De forma que Côrtes, até aquele momento, ao interior do espaço aids no Brasil, era um recém-chegado tanto no campo científico quanto no campo burocrático, desconhecendo as normas e os trâmites da tecnoburocracia estatal. Assim, foi a partir do momento em que assumiu a posição no ministério, onde começou a ganhar experiência na gestão. Além disso, tinha como fator complicador a ausência de prioridade dada pelo Ministro à epidemia da aids.

No período de março de 1990 a janeiro de 1992, quando Eduardo Côrtes esteve na direção do programa, não aconteceram reuniões da Cnaids. (BRASIL, 1994a; PROGRAMA NACIONAL DE DST E AIDS, 2003)

É importante ressaltar que a gestão de Côrtes iniciou-se quando a aids era manchete nas capas de revistas voltadas para o público feminino, como Contigo e Amiga, nas quais houve a divulgação de casos de artistas brasileiros, portadores de HIV/aids, a exemplo do cantor e compositor Cazuza e do ator Lauro Corona. A veiculação constante de notícias e a exposição de imagens quase que semanalmente em diferentes fases da doença, desde o diagnóstico - 1987 e 1988, respectivamente - até a morte dos artistas 1989, Lauro Corona e 1990, Cazuza - permitiram um acompanhamento da evolução da doença, evidenciada e materializada nos seus corpos. O preconceito em admitir a doença também apareceu, percebido através da reclusão e da omissão de informações ou na exposição dos fatos pela família e pelo próprio doente. (FAUSTO NETO, 1991) Da mesma forma, em 1991, foi massivamente divulgado, em âmbito internacional, o afastamento das quadras do jogador de basquete Magic Johnson, portador de HIV/aids.

83 As ONGS consideravam a campanha ameaçadora pelo apelo ao medo da aids e do doente de aids, assim como criticava a omissão do governo federal frente à epidemia de aids. 
Naquele período, houve, segundo o então coordenador do programa, uma tentativa de reestruturação da Comissão Nacional, incluindo a participação de esportistas e artistas, com objetivo de lhe dar maior visibilidade.

[...] eu sugeri que se criasse uma Comissão Nacional de Aids não de profissionais de saúde apenas, mas uma comissão da sociedade. Então quem ia fazer parte dessa sociedade? [...] Peléaceitou ser o presidente da nova Comissão Nacional de Aids e a gente começou a chamar pessoas da indústria, dos meios de comunicação, do meio científico. Então, o Pelé, vou te dar exemplo de algumas pessoas, muito conhecidas, representantes da sociedade. O Pelé, a Hebe Camargo, o João Araújo, que era o pai do Cazuza, que era uma pessoa muito influente nos meios, não era um homem público, mas era o cara que controlava a Som Livre, que era a maior gravadora brasileira [...]. O Paulo Ayrosa Galvão, que era o diretor do Hospital Emílio Ribas em São Paulo, queéo maior hospital de aids do Brasil. O Walter Clark, ele era um homem de TV também, ele tinha sido o executivo principal da Globo muitos anos e estava dirigindo as redes de TV educativas. Eu acho que ele tinha se aposentado, saído da Globo, mas era uma pessoa assim... [...] ele era brasileiro, de reconhecida competência nos meios de comunicação, enfim, eu tenho isso escrito e outras pessoas da área, tanto científica como... aí começou a ter um burburinho de gente querendo participar dessa comissão. (E7)

Essa proposta significaria uma mudança na composição da comissão e no seu caráter. A Cnaids passaria de uma comissão de especialistas dos campos médico, burocrático e do espaço associativo para uma comissão de personalidades/ pessoas famosas, talvez com maior visibilidade e capacidade de sensibilização da sociedade brasileira, mas com menor poder técnico e científico e mesmo com pouca representatividade dos diversos grupos, o que poderia resultar inclusive em uma menor legitimidade frente à elaboração da política e do discurso oficial. Contudo, com o retorno de Lair Guerra, em março de 1992, essa comissão não chegou a se concretizar. As pessoas chegaram a ser contatadas, a comissão foi divulgada no discurso do presidente Collor em comemoração ao dia mundial de combate à aids em 30 de novembro de 1991, mas não chegou a ocorrer nomeação dos membros ou reunião dessa comissão. 
O Boletim Epidemiológico também sofreu alterações na sua apresentação e na sua proposta editorial na gestão de Côrtes. Nos anos iniciais (1987-1989), o boletim era um veículo de comunicação do Programa Nacional que, além das informações epidemiológicas, apresentava textos acerca das principais questões em discussão, orientações do Programa Nacional, recomendações da Comissão Nacional, resultados de pesquisas ou mesmo análises da situação epidemiológica. Sua publicação era mensal, sempre relativa a quatro semanas epidemiológicas e impressa em papel branco nas cores vermelha e preta. ${ }^{84}$ (Figuras 3 e 4) Os dois primeiros números da gestão de Eduardo Côrtes mantiveram o formato anterior, trazendo a tradução de artigos publicados em revistas internacionais, além dos dados epidemiológicos.

A partir do $\mathrm{n}^{\circ} 10$, do ano III, referente às semanas epidemiológicas 14 a 22 de 1990, com objetivos de reduzir custos e buscando se assemelhar ao padrão internacional adotado pela OMS e pelos EUA, o Boletim Epidemiológico começou a ser impresso em tamanho ofício na própria gráfica do ministério, apresentação que só foi modificada no ano 2000, quando o meio eletrônico passou a ser a principal forma de difusão do boletim. A maior modificação foi na proposta editorial: o boletim passou a apresentar apenas os dados epidemiológicos consolidados em tabelas, sem qualquer relato, análise ou divulgação técnica de assuntos relacionados à epidemia da aids. (Figura 5) O editorial do Boletim $\mathrm{n}^{\mathrm{o}} 11$ informava que apresentaria artigos assinados por especialistas a partir da edição seguinte. O que, contudo, não aconteceu na gestão de Côrtes. O boletim deixou de ser um veículo de divulgação da política de aids e de estudos científicos, ficando restrito à informação epidemiológica consolidada em tabelas. Com o retorno de Lair Guerra, em 1992, foi mantida a forma de apresentação, mas a proposta editorial passou a incorporar novamente análises da situação epidemiológica, relatos de experiências e pesquisas científicas.

De acordo com um dos entrevistados, antes desse Boletim impresso em gráfica foram confeccionados artesanalmente alguns números com as primeiras informações epidemiológicas, contudo esses não foram localizados. (Entrevista concedida por E11, em São Paulo, em 4 de agosto de 2011) 


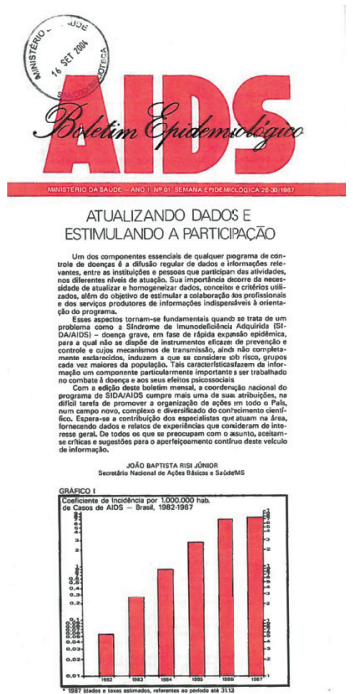

Fonte: Boletim Epidemiológico Aids (1987a).

FIGURA 4-Boletim Epidemiológico, parte interna

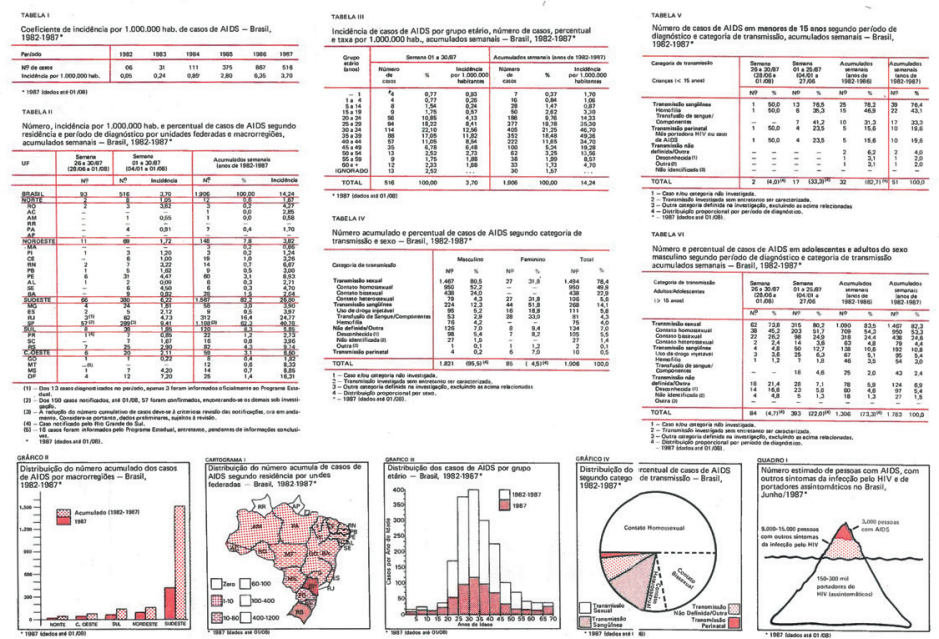

Fonte: Boletim Epidemiológico Aids (1987b). 

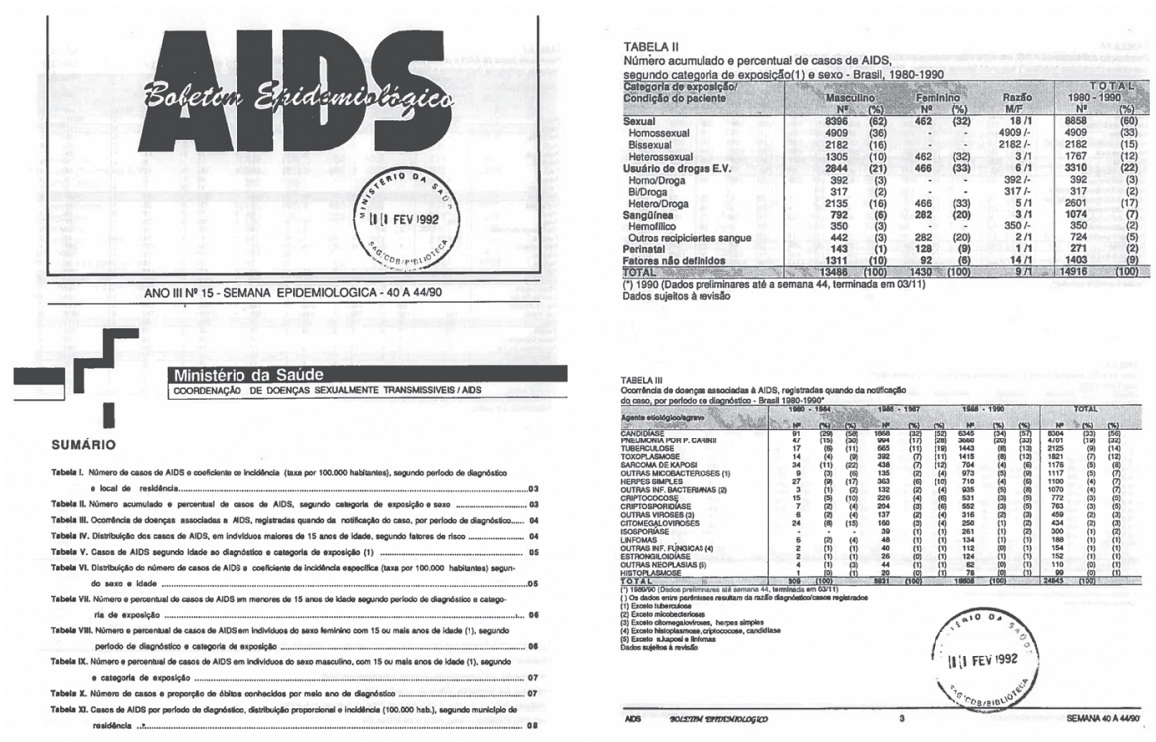

Fonte: Boletim Epidemiológico Aids (1990).

De acordo com Eduardo Côrtes, durante sua gestão, foi realizada uma revisão dos dados e incluído o procedimento de dupla digitação para identificação de erros. Existem referências a um atraso na publicação dos boletins na mudança da gestão de Lair Guerra para a de Côrtes, bem como uma irregularidade da publicação de números de acordo com Parker (2003). A análise dos boletins realizada no presente estudo, contudo, não foi capaz de evidenciar esse atraso, haja vista o período informado nos boletins ser referente às semanas epidemiológicas correspondentes ao período apresentado e não ao momento efetivo da sua publicação.

Com a mudança da equipe técnica, a suspensão das reuniões da Cnaids e a nova abordagem do Boletim Epidemiológico houve uma quebra nos canais de comunicação anteriormente estabelecidos entre Programa Nacional e organizações não governamentais, secretarias estaduais, médicos e pesquisadores, o que pode ter contribuído também para o isolamento do coordenador nacional. 
As críticas das ONGs/Aids estavam associadas principalmente à omissão do governo e à campanha educativa "Se você não se cuidar, a aids vai te pegar", considerada disseminadora de pânico e medo, contendo peças para a TV, a campanha tinha três fases previstas durante o ano de 1991. (GALVÃO, 2000; GOVERNO..., 1990; NASCIMENTO, 2005; PREVENÇÃO..., 1991)

[...] era uma campanha de longo prazo. [...] a gente foi criticado, mas a única avaliação que teve, no Correio Brasiliense, em dezembro de 1990, mostrou que mais de $80 \%$ da população tinha aprovado aquela campanha. Mas os entendidos de aids falaram que era um horror [...] Foi a primeira de uma série programada, em que a gente primeiro ia criar o choque, depois ia fazer a campanha contra o preconceito [...] As pessoas não queriam que a gente falasse isso. Não pode falar que a aids não tem cura. [...] Tirando as doenças infecciosas, amigdalite, pneumonia, tuberculose, sífilis, gonorreia, o que você cura? Você não cura diabetes, você não cura hipertensão arterial, você não cura cirrose, você não cura enfisema. A gente usava 'não tem cura', como nenhuma tem, mas não queriam dizer isso, e era aquela coisa, aquela dificuldade. [...]. (E7)

$\mathrm{Na}$ primeira fase, foi veiculado um filmete de 30 segundos com algumas pessoas falando, no estilo depoimento, cuja ideia, de acordo com E7, era “[...] comparar três doenças conhecidas com essa doença nova” e mostrar que todos são vulneráveis ao vírus, portanto deveriam se cuidar.

Eu tive tuberculose, eu tive cura.

Eu tive sífilis, eu tive cura.

Eu tive câncer, eu tive cura.

Eu tenho aids, eu não tenho cura.

Nos próximos dias, nos próximos meses, no próximo ano, milhares de pessoas vão pegar aids e vão morrer. Se você não se cuidar, a aids vai te pegar! (Campanha "Se você não se cuidar, a aids vai te pegar", 1991)

Essa primeira peça publicitária devido aos inúmeros protestos por parte das ONG/Aids, permaneceu pouco tempo no ar, segundo texto veiculado no endereço eletrônico do próprio Ministério da Saúde no qual 
está o vídeo. ${ }^{85}$ Vale destacar que esse é o único vídeo cujo texto explicativo refere a qual era o governo e o gestor do Programa Nacional à época da sua produção e a repercussão da campanha entre as ONGs, apresentando Eduardo Côrtes como diretor do Programa de Conscientização da Aids, termo não localizado em qualquer material do Ministério da Saúde ou na imprensa, que àquela época ainda era Divisão Nacional de DST/Aids, o que evidencia a relação conflituosa com o grupo que o sucedeu na gestão do Programa. (Figura 6)

FIGURA 6 - Endereço eletrônico do Departamento Nacional de DST, Aids e Hepatites Virais que apresentava o vídeo da campanha "Se você não se cuidar a aids vai te pegar", com destaque no texto que faz referencia ao governo e ao diretor do Programa Nacional à época

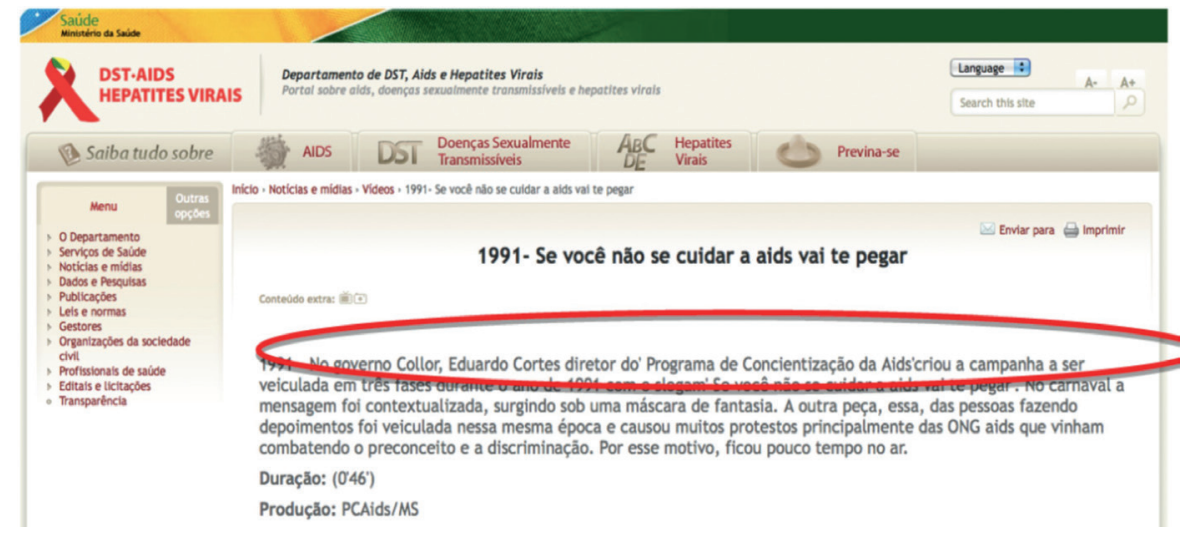

Fonte: $1991-$ SE VOCÊ... (1991).

A segunda fase da campanha tinha o objetivo de reduzir o preconceito e a discriminação dos portadores de HIV/aids: “abraço não dá aids, carinho não dá aids, respeito não dá aids, e terminava assim aids não tem cura, mas preconceito tem" (E7), enquanto a terceira fase abordaria as formas de transmissão da doença - relação sexual, agulhas e seringas compartilhadas, transfusão sanguínea e transmissão vertical. (CÔRTES, 1991) (Figura 7) A crítica dessa vez estava relacionada ao fato da campanha não tratar

85 Cf.SEVOCÊ..., 1991. 
do uso do preservativo como principal forma de prevenção. (LEIA..., 1991) Foi um período em que as ideias do gestor da política nacional não estavam em consonância com a opinião das ONGs e de especialistas que vinham se destacando no enfrentamento à epidemia no país, bem como, de pouca participação e articulação entre a burocracia estatal e os demais subespaços envolvidos na resposta à aids no Brasil. No final de 1991, o governo brasileiro negou-se a participar de um ensaio de vacinas na fase I, primeira que testa a vacina em humanos, junto com Uganda, Tailândia e Ruanda. (SAÚDE..., 1991) Conforme relatado pelo então coordenador, já havia ocorrido uma reunião três meses antes, com participação de representantes da OMS, na qual foi negociada a participação do país em um esforço conjunto com países da Europa e Estados Unidos. (E7)

Contudo, como o documento apresentado pela OMS, em dezembro de 1991, falava em transferência para a OMS da administração da pesquisa de vacinas no Brasil e definia os pesquisadores que iriam acompanhar a pesquisa, sem consulta prévia ao Ministério da Saúde, o ministro Alceni Guerra não aceitou participar nessas condições (SAÚDE..., 1991), posição à qual se opuseram as ONGs, que enviaram ao Ministério da Saúde um documento solicitando a continuidade do diálogo com a OMS e elaboraram a primeira edição ou o número zero do Boletim Vacinas Anti-HIV/aids, editado por um conjunto de ONGs (BELOQUI, 2003; DOSSIÊ..., 1992)

Paradoxalmente, nesse período se pode destacar pelo menos dois fatos importantes para a consolidação da política de controle da epidemia de aids no Brasil:

- O início da distribuição de AZT, pentamidina e ganciclovir pelo Ministério da Saúde em 1991. (SAÚDE..., 1991; TEIXEIRA, 1997)

- O início das negociações para o primeiro acordo de empréstimo junto ao Banco Mundial. (E7, E9; E27) ${ }^{86}$

Foi também nesse interim que ocorreu o primeiro pronunciamento de um presidente em cadeia nacional de rádio e TV sobre aids, em 30 de 
FIGURA 7 - Cartaz da campanha "Se você não se cuidar, a aids vai te pegar", esclarecendo as vias de transmissão

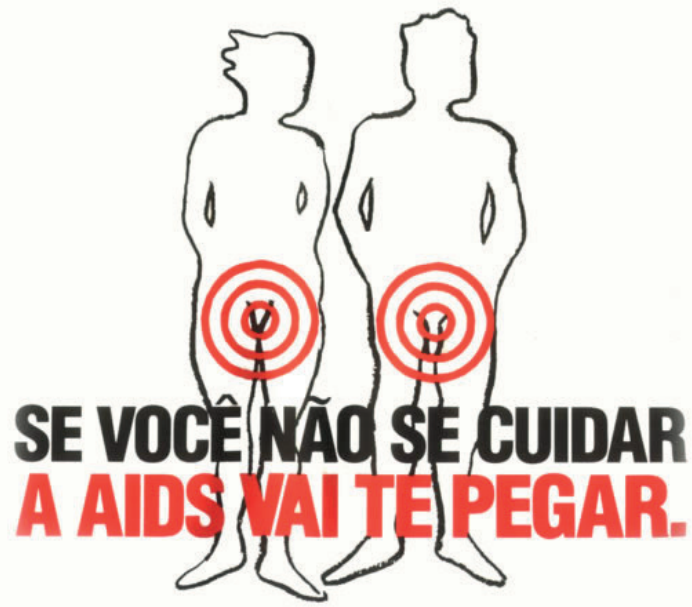

(2) ATRAVÉS DE RELACÃO SEXUAL

COM QUALQUER PESSOA CONTAMINADA.

(2) ATRAVÉS DE AGULHAS E SERINGAS CONTAMINADAS.

() NA TRANSFUSÃO OU CONTATO COM SANGUE CONTAMINADO.

(2) DA MÃE CONTAMINADA PARA O FILHO, DURANTE A GRAVIDEZ OU NO PARTO. 
novembro de 1991, em razão do dia mundial de combate à aids $-1^{\circ}$ de dezembro. (ANEXO C)

Mesmo que a decisão do Ministro Alceni Guerra em adquirir e disponibilizar medicamentos para a aids na rede pública tenha se dado em um momento de pressão e sem uma articulação prévia com outros setores do governo, ${ }^{87}$ como o Ministério do Orçamento, Planejamento e Gestão, que a oferta de medicamentos tenha sido escassa e irregular e que o acordo de empréstimo só tenha se efetivado em 1993, esses acontecimentos estruturaram a base para a consolidação da política nacional de aids na gestão seguinte. Pode-se destacar que a entrada de um médico clínico na gestão do Programa Nacional, com experiência prévia no tratamento de pacientes com HIV/aids em uma realidade diferente da brasileira, com acesso de medicamentos para o tratamento dos doentes, associado à pressão da mídia e das ONGs, contribuiu para o início da implantação de uma política nacional de acesso a medicamentos para o tratamento da aids. A incipiência da política, naquele momento, pode estar relacionada aos limites do desenvolvimento tecnológico de uma terapêutica eficaz e à irregularidade da oferta.

O pronunciamento do presidente Collor em cadeia nacional de TV e rádio foi o primeiro, e talvez o único, de um presidente abordando a questão da aids, o que evidencia a priorização da questão pelo governo federal a partir do segundo semestre de 1991. Aproveitando o interesse manifestado pelo presidente que passou a questionar o Ministro da Saúde sobre a doença, E7 diz que sugeriu o pronunciamento no dia $1^{\circ}$ de dezembro de 1991.

87 Eu fizuma previsão de custos e de remédios, eu tinha isso pronto. No dia que o Alceni me chamou lá porque a televisão estava lá e ia cobrar dele e ele me perguntou quanto custaria os remédios, eu disse '30 milhões de dólares'. [...] Foi a primeira vez que eu conversei com ele. Ele mandou me chamar lá correndo. [...] A nossa média de sobrevida era 6 meses. [...] Eu vias pessoas morrerem aos quilos, não tinha remédio, não tinha nada, não éAZT, eu estou falando de remédio, não tinha remédio pra tuberculose pras pessoas, porque não tinham previsto isso. Não tinha remédio pra tratar Pneumocystis carinii. Matava assim... você via as pessoas morrerem por falta de remédio! Aquele negócio, eu me sentia péssimo. Por isso que eu quis tanto organizar essa questão. [...] Não apenas do AZT, antes do AZT, eu já tinha conseguido aprovar pra tratar todas as infecções dos doentes de aids e isso foi assim uma mudança enorme. As pessoas estavam cegas, não tinham remédio, as pessoas morriam de Pneumocystis carinii, ficavam alérgicas ao Bactrim que era o que tinha e não tinha pentamidina. Não tinha, não tinha, simplesmente não tinha. (E7) 
[...] eu falei com o Alceni Guerra que era importante pro $1^{\circ}$ de dezembro, que o presidente da república devia falar sobre aids. [Ou] Ele poderia entrar para a história como alguns presidentes que se omitiram. Eu falei isso pro Alceni e ele falou pro Collor. E o Collor resolveu fazer o pronunciamento à nação pra comandar as comemorações do 10 de dezembro de 1991. (E7)

O discurso ocorreu no dia 30 de novembro, na noite anterior ao Dia Mundial de Combate à Aids, devido a uma viagem do presidente para a Colômbia no dia seguinte. O texto foi elaborado pelo cerimonial do Itamaraty, assessorado pela Coordenação de DST/Aids do Ministério da Saúde.

[...] dois jovens diplomatas que iam lá, que eram a interface do presidente comigo, [...] eles é que iam lá com o discurso do Collor, pra escrever junto comigo, e eu recheava a questão técnica. Foram três vezes com esse discurso, nas três eu colocava 'falar de camisinha', nas três o Collor tirou, entendeu? Não falou de camisinha. Mas eu colocava. [...] Eles iam lá 'e aí? Você tem que aprovar o discurso dele', eu recheava, recheava, colocava os gráficos e aí o Collor fez uns bonequinhos, fez lá os gráficos pra mostrar... Foi isso que aconteceu. Foio Itamaraty. Isso foicoordenado, provavelmente, pelo Marcos Coimbra, que era o Embaixador, que era acho o chefe da casa civil dele [...] E eu fiz a parte técnica do discurso. (E7)

O texto foi publicado na íntegra pelo jornal Folha de São Paulo, no dia $1^{\mathrm{o}}$ de dezembro (ANEXO C), Collor dizia que falava enquanto pai de dois adolescentes e Presidente da República. O texto dava destaque a questões técnicas, seus modos de transmissão e sua epidemiologia, apresentando informações sobre essa doença considerada uma emergência médica. A aids era caracterizada como uma doença sem cura, mas evitável, em expansão, que, apesar de ter acometido no início dos anos 1980 principalmente indivíduos do sexo masculino com práticas homossexuais, já apresentava, naquele momento, maior participação de heterossexuais e usuários de drogas injetáveis, predominando, entre esses últimos, adolescentes de 13 a 19 anos, bem como avanço para municípios de menor porte. Ou seja, a aids era apresentada como uma doença que ameaçava toda a população, em especial, os adolescentes. O texto destacava ainda a figura 
do soropositivo e a possibilidade de disseminação da doença através de milhares de pessoas que não sabiam estar contaminadas, mas poderiam transmitir a doença. $O$ discurso era contra o preconceito e a discriminação, promovia uma atitude cristã, de misericórdia e ajuda aos doentes, defendia a permanência dos doentes no exercício profissional, mas não mencionava o uso de preservativo - sexo seguro - como uma das formas de prevenção e afirmava que "a promiscuidade é uma forma de comportamento que atenta para a própria vida”, evocando a questão moral. Foram apresentadas as ações que o governo federal estava implantando:

- O estabelecimento de um programa de prevenção e assistência;

- A constituição da nova Comissão Nacional de Aids que teria por presidente o jogador Edson Arantes do Nascimento, o Pelé, com objetivo de "mobilizar a sociedade para essa importante missão de combate à epidemia";

- A distribuição de medicamentos, inclusive o AZT; e

- A descentralização do combate à epidemia para os municípios, através da criação de comissões municipais específicas. ${ }^{88}$

Por fim, conclamava toda a sociedade civil a se engajar na luta contra a aids e que a guerra contra a aids seria vencida "com a ajuda de todos e de cada um dos brasileiros, e, acima de tudo, com a ajuda de Deus”. A ambiguidade permeava todo o discurso, que dava ênfase ora à explicação técnica, clara e desprovida de preconceitos, ora ao componente religioso, a moral, e evidenciava o preconceito a determinadas práticas sexuais e mesmo ao modo de vida. Guerra levou a proposta de criar programas municipais de aids, como já havia sido implantado para outras doenças. [...] Ele mandou uma carta pra cada prefeito do país, eu que coordenei essa operação, falando sobre aids, da necessidade de se criar um programa nas cidades. (E7) 


\section{Da resposta samaritana à Pastoral da aids: a nova atuação da igreja}

A década de 1990 marcou o posicionamento da igreja católica voltada para a "resposta samaritana" (ARNS, 1995), baseada na compreensão, misericórdia, solidariedade e ajuda aos que sofrem, promovendo informações sobre a doença, a assistência aos enfermos, amigos e familiares, levando à formação de casas de apoio e atendimento domiciliar a soropositivos (CNBB, 1997; GALVÃO, 1997; PARKER, 2009), bem como o posicionamento contra a discriminação, como pode ser observado no caso da menina Sheila. (Quadro 7)

QUADRO 7-Caso Sheila

Em maio de 1992, a Confederação Nacional dos Bispos do Brasil (CNBB) repudiou a orientação do Sindicato dos Estabelecimentos de Ensino do estado de São Paulo (SIEEESP) de recusar como alunos crianças portadoras de HIV/aids. A decisão surgiu como resultado da consulta da escola Ursa Maior, que não aceitou a matrícula da menor Sheila Caroline Cortopassi de Oliveira, de 5 anos, que já frequentava a escola, depois de ter conhecimento que a menina era portadora do vírus HIV. O caso teve ampla divulgação na mídia. Além da CNBB, o médico Vicente Amato Neto, consultado pela justiça paulista, e a Sociedade Brasileira de Infectologia, representada pelo seu presidente Paulo Augusto Ayrosa Galvão e seu vice-presidente, André Vilella Lomar também se posicionaram contra a posição do SIEEESP e contra a discriminação dos portadores de HIV/aids. Sheila recebeu uma bolsa do Colégio São Luiz, tradicional colégio católico de São Paulo.

Fonte: Biancarelli (1992) e Galvão e Lomar (1992).

Apesar de pregar que a aids poderia atingir qualquer pessoa através da contaminação sanguínea, o discurso da CNBB continuava carregado de preconceito. A proposta era de uma educação sexual que resgatasse “a visão sadia da sexualidade humana", incentivando "a viver a fidelidade na união do homem com a mulher no matrimônio, superando formas de 
promiscuidade e libertinagem". (CNBB, 1997) Ponto de vista que se contrapunha àquele dos homossexuais, que priorizavam o prazer.

Embora o discurso não classificasse a homossexualidade como doença, a abordagem deixava clara essa visão. Excluídos os casos de contaminação através do sangue, a adoção de comportamentos baseados em valores de uma moral religiosa seria a única alternativa segura para evitar a doença. Nesse sentido, associava o sexo ao pecado e a aids era compreendida como uma punição. Considerava que o objetivo das campanhas promovidas por órgãos públicos e outras instituições era "transformar práticas de risco em práticas mais seguras”, mas que não eliminavam o risco da contaminação, o que só seria alcançado através da adoção dos princípios da moral cristã com relação ao valor da sexualidade, do seu uso e de sua abstinência. (CNBB, 1997)

Em 1995, D. Paulo Evaristo Arns passou a classificar o uso do preservativo como "um mal menor", ainda que não recomendasse o seu uso indiscriminado e tratasse a sexualidade como algo negativo. Sua fala também apontava para a adoção de uma linguagem mais popular, usando o termo camisinha, que a própria igreja católica considerava inapropriado nas primeiras campanhas.

Eu não recomendaria simplesmente a camisinha. Mas eu diria se, por exemplo, marido e mulher, que tem direitos, direito absoluto ao ato conjugal, se um deles tem [aids], então, é claro que deve prevenir, para que o outro não seja contaminado. Porque entre os dois males, sempre se deve escolher o menor. Agora, dizer, recomendar a todo mundo: 'Use camisinha e faça'..., não é? Olha, ela não é segura! Há 30\% de perigo de, sobretudo as nossas, 30\% de perigo. Em segundo lugar, o sexualismo desenfreado não ajuda a nação a crescer. Em terceiro lugar, nós, como governo, ou como igreja, ou como instituição, nós não temos o direito de dizer ao outro: 'Olha aqui, você pode fazer o sexo à vontade, desde que você se previna'. Eu acho que cada um tem que educar-se para que a vida em família seja realmente a base da sociedade. (ARNS, 1995)

No final do ano de 1997, o “irmão” Henrique Sá se destacou em uma visita de técnicos do Ministério da Saúde no estado do Amazonas. Tratava-se 
de um caboclo amazônico e pessoa vivendo com HIV/aids, que fundou um centro de atividades e de convivência em Manaus. Enfatizava a diferença entre proclamar e garantir direitos. Irmão Henrique foi o responsável pelas primeiras articulações entre o Programa Nacional, representado pelo seu diretor Pedro Chequer, e o presidente da CNBB, Dom Jaime Chamelo, que resultaram na criação da comissão de DST/Aids da Pastoral da Saúde em 1999. (CNBB, [20--]; COSTA FILHO, 2004) Em 2001, a comissão foi desvinculada da Pastoral da Saúde, sendo legalizada a Pastoral da Aids, tendo como bispo referencial Dom Eugênio Rixen. A Pastoral da Aids era um serviço de prevenção ao HIV e assistência aos soropositivos assumido pela igreja cujo logotipo unia dois símbolos: a cruz que representava a solidariedade e o laço vermelho, símbolo internacional da aids.

Assim como aconteceu com a política Estatal, que incorporou os princípios e diretrizes do que vinha sendo desenvolvido nos estados, na década de 1990, a CNBB incorporou no seu discurso o que já vinha sendo executado no nível local desde a década de $1980 .{ }^{89}$

\section{O papel do Banco Mundial na consolidação da política}

Apesar de não existirem provas documentais acerca da articulação do primeiro acordo de empréstimo em 1991, os relatos de agentes que ocupavam posições distintas e até mesmo opostas, no sentido de participarem de polos diferentes na disputa pela dominância no espaço aids (E7, E9 e E27), convergem nesse sentido.

89 Apesar dos avanços na relação entre Programa Nacional e igreja católica, em 2012, questões religiosas interferiram na divulgação da campanha prevista para o carnaval. Voltada para os jovens homossexuais de 15 a 24 anos, grupo que apresentou 10\% de aumento no número de casos entre 1998 e 2010, enquanto entre os heterossexuais do mesmo grupo etário houve redução de 20\% (BOLETIM..., 2011), a peça apresentava dois homens homossexuais e tinha como slogan "Na empolgação pode rolar de tudo. Só não rola sem camisinha. Tenha sempre a sua”. Mesmo após o lançamento da campanha no Rio de Janeiro com exibição do vídeo, a peça veiculada na TV pelo Ministério da Saúde foi substituída por outra na qual um casal heterossexual falava de dados estatísticos que mostravam o crescimento da infecção entre jovens gays e da redução do uso do preservativo. O veto teria vindo do Palácio do Planalto segundo o Departamento de DST/Aids e Hepatites Virais do Ministério da Saúde, e era atribuído ao receio do governo em contrariar grupos religiosos. A informação foi negada pelo Ministro da Saúde, Alexandre Padilha. (FORMENTI, 2012) 
Quando o programa de aids passou a ser prioridade no Ministério da Saúde, sabe, aí nós fomos incluídos para o financiamento do Banco Mundial." (E7)

Uma outra coisa que o Alcenifez, foi aceitar uma proposta do Banco Mundial para firmar um acordo de empréstimo para o 'PN'. Ele indicou, isso eu quero dizer sem provas documentais, o Edmur Pastorello, para negociar junto ao Banco. O Edmur me chamou. Foi o Edmur e eu que fizemos a carta de intenção para apresentar ao Banco, com 'palpites' do Pedro Chequer. [...] O Acordo de Empréstimo com o Banco Mundial só foi assinado, que passa pelo Senado, o Ministério da Fazenda e tudo mais, pelo Ministro Adib Jatene, mas foi uma iniciativa do Ministro Alceni Guerra. A verdadeira iniciativa, por parte do Banco Mundial, foi da Maureen Lewis, uma norte-americana que passou a adolescência aqui no Brasil. (E9)

Em 1991. Na época, Edmur Pastorello, que é da USP, trabalhava como assessor do ministério para o Alceni Guerra. Ele convidou o Euclides. Eu era uma pessoa anátema, por que antes eu trabalhei [...] como diretor do Cenepi, na época do cólera. E como o ministro Alceni Guerra quis esconder os óbitos, eu denunciei, [...] ele me mandou para o Acre, não podia me demitir porque eu era estável no governo e ai o Euclides me chamou escondido porque ele não podia saber que eu estava envolvido. Ai se fez as duas, três primeiras páginas do que seria o embrião do projeto de acordo do Banco Mundial, que o Dr. Adib Jatene assumiu. [...] Nós fizemos uma reunião no prédio da Funasa, no anexo que ficou a Funasa, onde depois passou a ser Cenepie agora não sei o que émais, não é mais Cenepi por que Cenepi não existe mais. E ai nós discutimos alguns princípios e tal, que o Pastorello utilizou e depois o Pastorello continuou com o Adib porque como era da USP, terminou continuando e a coisa aconteceu do primeiro acordo de empréstimo. (E27)

O Banco Mundial já havia financiado, através do Projeto Nordeste, um montante de 7,4 milhões de dólares para o controle e prevenção da aids, recurso que permitiu a elaboração de campanhas veiculadas na imprensa e de materiais educativos, bem como aquisição de equipamentos e materiais para bancos de sangue e laboratórios de saúde pública, contribuindo para a estruturação do Programa e na preparação do acordo de empréstimo específico. (THE WORLD BANK, 1997) Mas foi o Brasil que buscou o Banco para o financiamento da sua política de HIV/aids, em um momento 
em que este ainda hesitava em financiar ações relacionadas à epidemia da aids, não considerado um investimento produtivo por parte dos economistas. (BEYRER; GAURI; VAILLANCOURT, 2005) O financiamento de projetos específicos para controle da aids pelo banco estavam restritos ao Zaire (1989) e à Índia (1991), ainda que diversos projetos incluíssem componentes para o controle da aids e DSTs. (THE WORLD BANK, 1993)

Com inúmeras denúncias de irregularidades, o ministro Alceni Guerra deixou o cargo em 23 de janeiro de 1992. O Ministério da Saúde foi assumido interinamente pelo Ministro da Educação, o físico José Goldemberg, que acumulou as duas funções até 13 de fevereiro, quando o médico cardiologista Adib Jatene assumiu o cargo. (VAZ, 1992)

Eduardo Côrtes permaneceu no Programa Nacional até a chegada de Jatene, quando foi substituído pela sua antecessora, Lair Guerra. A permanência de Edmur Pastorello ${ }^{90}$ na assessoria ao Ministro Adib Jatene teria permitido a continuidade do processo de negociação junto ao Banco Mundial e, sob a coordenação de Lair Guerra, o projeto foi concluído, tendo contado com a consultoria de vários ativistas na sua elaboração. O projeto seguiu então para tramitação na Câmara dos Deputados e no Senado.

Com o impeachment do presidente Collor no final de setembro e a entrada de Itamar Franco, iniciou-se um novo período na saúde, mas mesmo com a troca de Ministros, ${ }^{91}$ Lair Guerra manteve-se na coordenação do Programa Nacional de Aids.

Médico sanitarista e professor doutor do Departamento de Epidemiologia da Faculdade de Saúde Pública da USP. Entre 1980 e 1983, foi diretor Divisão Nacional de Doenças CrônicoDegenerativas (DNDCD) do Ministério da Saúde, e superintendente da Campanha Nacional de Combate ao Câncer, de 1980 a 1985. Foi diretor do Instituto de Saúde da SES-SP entre 1987 e 1989, e secretário geral do Ministério da Saúde de 1989 a 1990. Em 1992, foi Diretor de Operações da Fundação Nacional de Saúde e depois Chefe de gabinete do Ministério da Saúde, função que assumiu também entre 1995 e 1996. Na SES-SP, em 1993 coordenou os Institutos de Pesquisa, entre 1997 e1999 assumiu a coordenadoria de Planejamento de Saúde, e em 1999 foi assessor técnico de gabinete. Entre 2002-2003 foi diretor técnico-científico da Fundação Oncocentro de São Paulo, da qual foi diretor-presidente entre 2003 e 2011. (INCA, 2012)

91 Durante o governo Itamar Franco, no período de outubro de 1992 a agosto de 1993, o Ministro da Saúde foi o médico Jamil Haddad, sucedido pelo também médico Henrique Santillo, que permaneceu no cargo até o final do governo Itamar em 1 de janeiro de 1995. 
O primeiro acordo de empréstimo junto ao Banco Mundial foi assinado em 1993, após duas missões do Banco, ${ }^{92}$ a primeira realizada em outubro de 1992 e a segunda em janeiro de 1993.

Também conhecido como AIDS I, o projeto tinha como objetivos gerais a redução da incidência e transmissão do HIV e de DSTs; e o fortalecimento de instituições públicas e privadas responsáveis pelo controle de DSTs e HIV/aids, através de um aporte financeiro de 250 milhões de dólares, 160 milhões do Bird e 90 milhões do governo federal, distribuídos em 4 componentes:

1. Prevenção (U\$93,9 milhões): programas de informação, educação e comunicação voltados para o público geral e grupos de alto risco; ampliação da capacidade de diagnóstico, aconselhamento, testagem e intervenções precoces; aquisição e distribuição de preservativos;

2. Serviços (U\$75,7 milhões): serviços de saúde para pacientes com HIV/aids e DSTs; integração de prevenção e serviços médicos ao aconselhamento visando melhorar e reduzir os custos da assistência;

3. Desenvolvimento institucional ( $\mathrm{U} \$ 42,3$ milhões): treinamento de profissionais de saúde, melhoria de serviços laboratoriais e assistência técnica; e

4. Vigilância, Pesquisa e Avaliação (U\$14,6 milhões): ${ }^{93}$ vigilância epidemiológica, avaliação do programa e estudos especiais, incluindo análises epidemiológicas, de custos, e impacto econômico do HIV/ aids. (BEYRER; GAURI; VAILLANCOURT, 2005; THE WORLD BANK, 1993)

A primeira missão composta por M. Lewis (líder da missão), M. Jacobs (analista de operações), R. Hoffman (oficial de operações), J. Wilson (consultor), K. Holmes (consultor), M. Moore (consultor), E. Ayres Castilho (consultor) eS. Dompieri (consultor); a segunda, por M. Lewis (líder da missão), M. Jacobs (analista de operações), J. Wilson (Consultor), C. Bertao (assessor sênior), E. Ayres Castilho (consultor), S. Dompieri (consultor), D. Schopper (consultor) e F. Zacharias (consultor).

Um montante de U\$23,5 milhões foi reservado para contingências físicas e de preço. 
O maior volume de recursos estava alocado no componente Prevenção, corroborando a política do banco, que não aconselhava o investimento em tratamento para países em desenvolvimento. Assim, banco e governo chegaram a um acordo com relação à política de fornecimento de medicamentos antirretrovirais: o banco não concordava com o fornecimento de AZT garantido pela política brasileira, visto que considerava o tratamento caro e não efetivo, e exigia a redução de taxas de importação para preservativos, permitindo uma redução do preço final ao consumidor. (BEYRER; GAURI; VAILLANCOURT, 2005)

\section{[...] Esseéum dos artigos que nós estamos trabalhando desde o primeiro momento, desde 1991, 92, 93, a gente já defendia que tratamento era prevenção, que o acesso ao tratamento era prevenç̧̃̃o. (E3O) $)^{94}$}

Um indicador importante da qualidade e efetividade do serviço para o Banco Mundial foi a baixa prevalência de resistência a medicamentos ARVs (6,6\%) documentada por um estudo ${ }^{95}$ realizado em 2003 no Brasil. (THE WORLD BANK, 2004a) Até 2012, contudo, não havia sido monitorada a possibilidade de reversões de comportamentos - no sentido de comportamentos de maior risco - em consequência do programa de tratamento bem-sucedido do país.

Os resultados obtidos levaram inclusive o grupo de avaliação do banco a ratificar a importância do fornecimento de medicamentos ARVs, quando considerou que tanto o AIDS I como o AIDS II, assinado em 1998, foram fundamentais para investimentos em capacitação para tratamento e assistência que viabilizaram a sua adoção. (THE WORLD BANK, 2004a)

O primeiro acordo de empréstimo foi executado entre os anos de 1994 e 1998, tendo importante papel no estabelecimento de financiamentos para as ONGs, Estados e municípios e na criação de uma estrutura adequada ao funcionamento do programa, tornando-o capaz de induzir de fato uma política nacional, inclusive legitimando atividades controversas

94 Entrevista concedida por E30, médica infectologista e diretora IPEC/Fiocruz, no Rio de Janeiro, em 14 de junho de 2011. 
de prevenção como a redução de danos, ${ }^{96}$ trabalho com presidiários e programas para profissionais do sexo. (BEYRER; GAURI; VAILLANCOURT, 2005; THE WORLD BANK, 2004a)

O segundo acordo de empréstimo, o AIDS II, vigente entre 1999 e 2002, teve um custo total de U\$296,6 milhões, 99\% do estimado - 300 milhões de dólares, sendo 165 milhões do Bird e 135 milhões do governo federal. Apesar de não ter recursos para medicamentos, teve investimentos para promover hospitais-dia, assistência domiciliar terapêutica, e outros serviços a pacientes não internados; diminuir o custo de preservativos, através de redução de impostos e outros meios; implantar um sistema de monitoramento e avaliação; e fortalecer a gestão de estados e municípios, devolvendo algumas responsabilidades. (THE WORLD BANK, 2004a)

O governo tornou-se fonte importante de financiamento para as ONGs. Com o AIDS I (1994-1998), 181 ONGs receberam financiamento para 444 projetos na área de prevenção, nos quais foi mais importante a atuação dessas organizações, e 140 projetos de tratamento e assistência, superando a meta inicial de 261 projetos financiados, o que foi viabilizado devido à redução do teto de financiamento de U\$ 100.000 para U\$ 50.000, devido à constatação que poucas ou nenhuma das ONGs tinha capacidade para usar aquela quantia. No AIDS II (1999-2002) esse número foi ainda maior. Foram financiadas 795 instituições, que executaram 2163 projetos - 1709 de prevenção e 454 de tratamento e assistência. (THE WORLD BANK, 2004a)

O aumento de casos entre usuários de drogas injetáveis a partir de 1989 levou à primeira iniciativa de programa de trocas de seringas, na cidade de Santos, São Paulo, com o médico Fábio Mesquita à frente do Programa Municipal. Porém a implantação da medida foi questionada pela Procuradoria do Município de Santos, baseada nos artigos 12 e 13 da Lei 6368/76, que trata das medidas de prevenção e repressão ao tráfico ilícito e uso indevido de substâncias que causem dependência física ou psíquica, considerava que a prática de troca de seringas estaria incentivando ao uso de drogas e, portanto, seria um delito, levando ao adiamento do programa de troca de seringas. A Secretaria de Saúde do estado de São Paulo, desde o início da década de 1990 também já vinha desenvolvendo estratégias de redução de danos, mas limitados pelajustiça paulista, apenas orientavam a limpeza das seringas com hipoclorito de sódio, o que era insuficiente. Assim, em 1995, Salvador foi a primeira cidade do Brasil a ter um programa de troca de seringas. Na sequência, outros estados e municípios começaram a criar legislações próprias, e apenas em 2002 foi aprovada a nova lei de drogas no país, permitindo "ao Ministério da Saúde regulamentar as ações que visem à redução de danos sociais e à saúde”. (BRASIL, 2002, Art. 12) 
Os projetos de assistência e tratamento executados por ONGs referiam-se a alojamento para pacientes em tratamento fora do domicílio, grupos de apoio, reinserção social, apoio para geração de renda, apoio domiciliar, apoio psicossocial, serviços de saúde mental e assistência voltados para a avaliação e aderência à terapia antirretroviral, além da criação de casas de apoio para pessoas vivendo com HIV/aids. (THE WORLD BANK, 2004a)

Verifica-se um aumento considerável do número de ONGs financiadas entre o primeiro e o segundo acordo de empréstimos. Ainda que não tenha sido possível realizar uma análise mais criteriosa acerca da ampliação do número de ONGs/Aids a partir do AIDS I, alguns entrevistados destacam ter surgido diversas organizações que se tornaram dependentes do financiamento governamental.

Os recursos oriundos dos projetos AIDS I e II teriam contribuído para a melhoria da qualidade dos serviços de diagnóstico, tratamento e assistência para pessoas com HIV/aids e DSTs, e sua expansão para todas as unidades federativas. Além de fomentarem o fortalecimento e a criação de coordenações estaduais nos 27 Estados e 150 coordenações municipais, os projetos também permitiram as primeiras transferências financeiras diretas para governos estaduais e municipais. Essas transferências estavam condicionadas à elaboração de planos operativos de ação (POA). Foram criados 237 centros de testagem e aconselhamento (CTA); foi desenvolvida uma rede de serviços especializados de saúde para pacientes com HIV/ aids; houve um fortalecimento do sistema de laboratórios para monitoramento e acompanhamento de pacientes; foram desenvolvidos softwares para gerenciamento e controle da distribuição e do uso de medicamentos antirretrovirais (Siscel e Sisclom); e realizados treinamentos de profissionais de saúde e outros quadros técnicos. (THE WORLD BANK, 2004a)

$\mathrm{Na}$ visão de alguns membros da Abia, como Raldo Bonifácio, João Guerra, Jane Galvão, Rogério Gondim, Alvaro Matida, Gerson Noronha, Richard Parker e Nelson Solano Vianna, “com esse projeto, o Ministério manifesta sua intenção de superar - de uma vez por todas, esperamos - os 10 anos de imobilismo e irresponsabilidade governamental que permitiram a desenfreada propagação do HIV em nosso país". (SCHWARZSTEIN, 
1993) Contudo, demandavam uma gestão democrática, transparente e eficaz, acompanhada por uma Comissão Nacional que pudesse efetivamente exercer o papel de controle social; e consideravam o AIDS I um "atalho metodológico" à elaboração de uma proposta de Programa Nacional adequada ao perfil epidemiológico, desconhecido devido à não realização de estudos de soroprevalência anteriores; questionavam a impossibilidade de compra de medicamentos e remuneração de profissionais e a capacidade de cumprimento da contrapartida financeira pelo Estado brasileiro e criticavam também o tempo exíguo para a elaboração da parte do projeto referente a cada estado.

O tempo que nos foi dado [...] foi extremamente curto. [...] Tudo foi feito a toque de caixa. Mesmo as pessoas responsáveis pela Coordenação do programa Estadual de DST e AIDS estavam desinformadas. As exigências eram grandes e as planilhas que recebemos foram decifradas com enorme dificuldade. O pessoal encarregado de coordenar o processo tentou descentralizar e democratizar, tentou conseguir o maior envolvimento possível por parte dos serviços públicos e das ONGs e isso foi bom... Aconteceu que por falta de tempo e de orientação suficientes muitos dos projetos que recebemos dos serviços públicos não tinham cabimento. [...] O que acontece é que a principal carência dos serviços já existentes diz respeito à falta de pessoal e de medicamentos, e que o Projeto do BM não contempla este tipo de necessidade. (BONIFÁCIO, 1993, p. 9)

Quando questionados acerca do significado dos acordos de empréstimo para o Programa Nacional, os entrevistados de todos os subespaços destacam a sua importância para a estruturação do Programa Nacional, relacionada à contratação de técnicos, financiamento de projetos de ONGs e projetos de pesquisa, na opinião de agentes do campo científico; à melhoria da rede de assistência, melhoria da governança e da gestão, e a possibilidade de contratação de bons profissionais, de acordo com os militantes e na visão dos agentes do campo burocrático; a possibilidade de financiamento de ONGs e transferência de recursos para estados e 
municípios, realização de inquéritos, priorização de populações vulneráveis e aquisição de equipamentos como computadores. (Figura 8)

Vale destacar que, em 1996, o sociólogo Betinho achava que, mesmo com o financiamento do Banco Mundial, o Programa Nacional ainda não estava consolidado, queixando-se principalmente com relação à insuficiência da assistência e tratamento no país e à dificuldade de acesso aos medicamentos, evidenciando um ponto de vista crítico de esquerda acerca da política nacional. ${ }^{97}$

Outro ponto destacado por agentes dos subespaços burocrático e científico foi a questão da manutenção da autonomia nacional frente à tentativa de indução de políticas pelo Banco Mundial que considerava a prevenção como única via para países em desenvolvimento. (Figura 8)

Essa autonomia esteve presente desde o início, quando Lair Guerra não aceitou a criação de uma gerência do projeto paralela ao Programa Nacional, prática frequente nos acordos de empréstimos do Banco Mundial, e foi fundamental para o fortalecimento do Programa Nacional de Aids. (E27)

Obanco queria estabelecer uma gerencia do projeto do Banco Mundial [...]. A Lair foi dura com isso, não aceitou, e onde isso aconteceu o programa não subexistiu. [...] Isso não funciona. Eu estive na Argentina e também apoiei o Banco na formação do projeto da Argentina e lá eles fizeram a gerência do projeto LUSIDA e o Programa de Aids do nível nacional, do Ministério da Saúde. O programa nunca conseguiu deslanchar, o projeto acabou e o programa não se beneficiou [...] (E27)

Nesse sentido, posteriormente, em 2005, na segunda gestão de Pedro Chequer, o país recusou um recurso da ordem de U\$40 milhões da U.S. Agency for International Development para aquisição de preservativos, por discordar da exigência de condenação da prostituição, como previsto nas leis norte-americanas. Tal condição foi rejeitada pelo diretor do publicadas no Boletim ABIA, n. 31, jan./abr. 1996. 
FIGURA 8 - Concepções dos entrevistados acerca do significado dos acordos de empréstimo junto ao Banco Mundial para o Programa Nacional de DST/Aids, segundo subespaços de inserção dos agentes

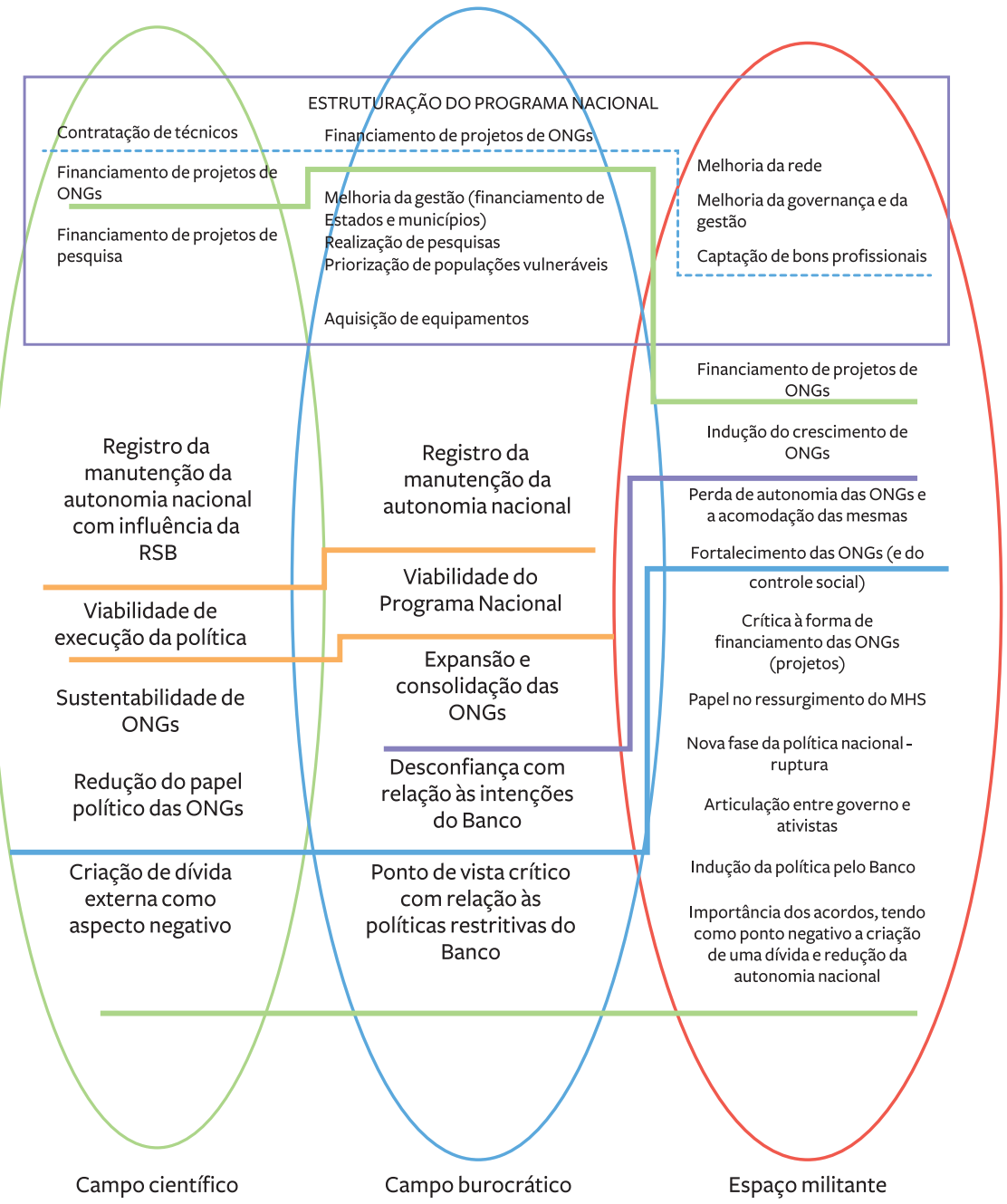

Fonte: Elaborada pela autora.

Nota: $O$ Apêndice $D$ apresenta as falas dos agentes que resultaram na elaboração dessa Figura. 
programa visto que no Brasil, a prostituição não é criminalizada, ${ }^{98}$ e desde 2002, a ocupação de "profissional do sexo" faz parte da Classificação Brasileira de Ocupações (CBO) na categoria "prestador de serviço" (RODRIGUES, 2009), além dessa categoria profissional ser parceira na execução das suas políticas, inclusive com representação na Cnaids.

O AIDS I marcou uma nova fase para a política nacional de controle da epidemia e também para o espaço aids, determinando uma transformação nas relações entre o campo burocrático e os demais subespaços. Com relação ao espaço militante, com a possibilidade de financiar projetos de ONGs, os recursos do Programa Nacional passaram a representar a sustentabilidade de algumas associações específicas de luta contra a aids, em especial as de menor porte e com menor capacidade de captação de recursos internacionais, gerando uma certa acomodação e em alguns casos dependência do Programa Nacional, o que também garantiu ao Estado maior controle em relação ao espaço aids. O projeto estimulou o diálogo com gays, usuários de drogas injetáveis, profissionais do sexo e, na opinião de Edward MacRae, teve também um impacto importante no movimento homossexual, promovendo o seu ressurgimento, através do estímulo a publicações, campanhas e ações voltadas para esse grupo específico.

Eu acho que ao mesmo tempo que foi uma ajuda grande, deu esse retrocesso. [...] Eu acho que atrapalhou por causa disso, as pessoas se acomodaram com os financiamentos de 30 mil, 40 mil, 50 mil, e pararam de reivindicar qualquer coisa. Ou só fazia isso porque o próprio Ministério dava o título. Então esse ano era mulher, então só vou trabalhar com mulher. [...] A epidemia tem tema? Não, então... Se eles mesmos falam, não tem, não escolhe partido, não escolhe segmento, não tem preconceito com nada, a aids gosta de todo mundo, como éque vai escolher um tema? (E3)

[...] esse financiamento levou, bom, toda essa ideologia do Banco Mundial, levou então o Programa de Aids do Brasil a começar a buscar cada vez mais um diálogo

De acordo com o Código Penal brasileiro (BRASIL, 1940), são crimes: induzir ou atrair alguém à prostituição ou outra forma de exploração sexual, facilitá-la, impedir ou dificultar que alguém a abandone (Art. 228); manter, por conta própria ou de terceiro, estabelecimento em que ocorra exploração sexual (Art. 229) e tirar proveito da prostituição alheia (Art. 230). 
com os gays, inicialmente, e depois com os usuários de drogas. Especialmente com os gays. [...] com esse trabalho, o Banco Mundial e o governo brasileiro, querendo ter contato com os gays e promover essas campanha entre os gays, eles começaram a financiar publicações, a financiar reuniões e isso deu um novo ímpeto para o movimento gay. Então o primeiro movimento gay foi assim uma reação contra os médicos, o segundo movimento já começa, de certa forma, caudatário, e vai perdendo a sua estridência, a sua crítica contra o establishment médico. Porque eles passam de críticos a porta-vozes. [...] Foi o dinheiro da aids que financiou esse ressurgimento do movimento gay. (E8)

O financiamento de projetos de ONGs foi um aspecto destacado por agentes de todos os subespaços. Esse financiamento foi considerado como positivo no sentido de promover uma maior articulação com as organizações não governamentais, possibilitando a expansão do número de associações e a sua consolidação, mas alguns militantes e agentes do campo científico destacaram como aspectos negativos a perda da autonomia das ONGs, a acomodação e a redução do seu papel político. (Figura 8)

As normas do banco só permitiam o financiamento de projetos, não existindo a possibilidade de apoio institucional, como garantido por algumas agências internacionais. Um entrevistado chegou a falar em uma "ditadura do projeto". ${ }^{99}$ O que foi também notado por alguns dos entrevistados foi uma redução das críticas ao Programa Nacional por parte das ONGs, compreendido por alguns como cooptação, mas por outros como um resultado da possibilidade de contratação de militantes/ativistas - garantida pelo acordo de empréstimo - para os diferentes níveis da gestão das políticas de aids, contribuindo para um aumento da capacidade técnica do Programa Nacional e também de programas estaduais e municipais, que associado à estruturação decorrente do aporte financeiro do acordo de empréstimo, possibilitou uma política mais efetiva, da qual eles são partícipes, também contribuindo para a redução das críticas. (Figura 8)

O fato de se tratar de um empréstimo foi destacado como ponto negativo, ainda que compreendido como necessário. Da mesma forma, foram 
citados por E6, casos pontuais de desvios, que na sua avaliação não superariam os benefícios do financiamento.

[...] eu acho que o recurso do acordo, há muita crítica porque o país paga, o país tem que pagar essa dívida, mas tem vários estudos, inclusive feitos por grupos franceses, do uso desses recursos, e que eu acho que eles tem uma avaliação positiva [...] $(\mathrm{E} 16)^{100}$

[...] uma parte dessas ONGs se constituíram por conta do financiamento. Enquanto teve dinheiro, elas funcionaram e na hora que acaba o financiamento, elas fecham. Teve muito problema com ONGs. Eu venho de ONGs eu vejo aqui mesmo, vocêtem desvios que aconteceram, pequenos, acho isso dentro do contexto geral, nós fizemos uma avaliação que é importante continuar financiando mesmo com alguns problemas localizados que aconteceram, mas tem assim, hoje acho que étambém um outro perfil dessas ONGs que estão sobrevivendo e algumas com muita dificuldade. A gente tem, por exemplo, Abia aqui do Rio Janeiro, instituição super-reconhecida, tem um belo trabalho com dificuldade por quê?? Porque ela teve para além do governo federal, muitos outros investimentos de fundações internacionais que hoje diminuíram e no mundo está diminuindo esse investimento. A gente precisa continuar. Esse é o desafio de continuar mantendo a prioridade e o investimento dos países ricos. $(\mathrm{E} 6)^{101}$

Os recursos dos projetos AIDS I e II permitiram iniciar a estruturação da rede de assistência aos portadores do vírus e da rede pública de laboratórios, fundamentais para o apoio à estratégia de acesso aos medicamentos ARV, mas, de acordo com a avaliação do banco, o país não avançou na questão da avaliação das estratégias implementadas. (BEYRER; GAURI; VAILLANCOURT, 2005; THE WORLD BANK, 2004a) No sentido de superar essa situação, em 2003, foi criado um setor de avaliação na Assessoria de Planejamento e Avaliação (Asplav), que elaborou o Plano Nacional de Avaliação (PNA) do PN DST/Aids, que como parte das suas

100 Entrevista concedida por E16, médica epidemiologista e pesquisadora, em Salvador, em 5 de setembro de 2011.

101 Entrevista concedida por E6, diretor adjunto do Departamento de DST, Aids e Hepatites Virais, em Brasília, DF, em 2 de agosto de 2011. 
estratégias promoveu a realização de cursos de pós-graduação - especialização e mestrado profissionalizante - em Avaliação de Programas de Controle de Processos Endêmicos, com ênfase em DST/HIV/aids, oferecidos pela Fiocruz e o sistema de monitoramento do Programa de Controle de DST/Aids e hepatites virais (Monitoraids). (SANTOS; REIS; CRUZ, 2010; THE WORLD BANK, 2004a)

Até 2012, o governo federal havia realizado quatro acordos de empréstimo junto ao Banco Mundial para o controle da aids no país. A análise dos valores desses acordos apontam para uma redução do montante de recursos bem como da participação do banco no acordo, com maior contrapartida federal, denotando o aumento da sustentabilidade e independência financeira da política brasileira de controle da aids. (Quadro 8)

QUADRO 8 - Acordos de empréstimo para o controle da aids, período de aplicação, montante total, participação do Banco Mundial e do Governo Brasileiro, 1993-2010

\begin{tabular}{|c|c|c|c|c|}
\hline $\begin{array}{l}\text { Acordo de } \\
\text { empréstimo }\end{array}$ & $\begin{array}{l}\text { Período } \\
\text { (assinatura-encerramento) }\end{array}$ & $\begin{array}{l}\text { Montante total } \\
\text { (em US\$) }\end{array}$ & $\begin{array}{l}\text { Banco } \\
\text { (em US\$) }\end{array}$ & $\begin{array}{l}\text { Governo brasileiro } \\
\text { (em US\$) }\end{array}$ \\
\hline AIDSI & 1993-1998 & 250 milhões & 160 milhões & 90 milhões \\
\hline AIDS II & $1998-2003$ & 300 milhões & 165milhões & 135 milhões \\
\hline AIDS III & $2003-2007$ & 200 milhões & 100 milhões & 100 milhões \\
\hline AIDS-SUS ${ }^{1}$ & $2010-2014$ & 200 milhões & 67 milhões & 133 milhões \\
\hline
\end{tabular}

Fonte: The World Bank (199, 2004b, 2008, 2010).

(1) Em 2014, o governo brasileiro assinou um termo aditivo ao acordo de empréstimo, que estendeu o prazo do acordo e cancelou US\$25.150.00o de dólares do valor total do empréstimo, passando ao valor de US\$ 41.850.00. (THE WORLD BANK, 2014)

\section{Cnaids: nova relação de forças}

Pode-se destacar duas fases da Comissão Nacional de Aids, a primeira do início da sua implantação até o início dos anos 1990, quando já existiam as primeiras possibilidades terapêuticas. Neste primeiro momento, a voz dos especialistas que conformavam a Cnaids era muito importante para a construção do discurso oficial e, além do papel consultivo, as tomadas de posição da comissão eram acatadas e repercutiam na condução da política, de modo que a mesma parecia possuir de fato um papel deliberativo, ainda que esse não lhe fosse delegado oficialmente. 
Após a gestão de Eduardo Côrtes (1990-1992), na qual não houve reuniões da Cnaids, a comissão foi retomada na nova gestão de Lair Guerra. Com a maior estruturação da política nacional, entre 1992 e 1993, surgiram outras instâncias de assessoramento ao Programa Nacional, como o comitê de vacinas, a comissão para estudos e ações no sistema penitenciário, o comitê de pesquisa, e um setor específico de articulação com as ONGs, levando a um esvaziamento das funções da Cnaids, que na primeira gestão de Lair Guerra constituía-se como único espaço de discussão e articulação da política.

A Comissão Nacional foi descrita pelos entrevistados como uma instância de assessoria técnica e política ao Programa Nacional. Consultiva, sem poder de deliberação, mas com influência na tomada de decisões em função da sua capacidade técnica, por se tratar de um grupo de experts. Alguns a consideraram como instância de controle social e quase todos destacaram a grande diversidade de atores como um fator positivo. (APENDICE E)

Segundo o ponto de vista de alguns entrevistados, o surgimento dessas novas instâncias estava relacionado à complexidade que a resposta governamental adquiriu, à entrada de novos agentes no espaço aids e aos avanços no saber médico acerca da doença, bem como a formação de uma expertise em diversas áreas. Ou seja, à medida que o espaço aids foi especializando-se, seja no campo médico ou no burocrático, foram surgindo novas instâncias de participação e articulação do Estado com os demais campos e subespaços interessados no controle da epidemia (APÊNDICE E), refletindo as disputas ao interior do espaço entre médicos e sanitaristas e militantes com a criação de espaços técnico-científicos.

A comissão assumiu o papel de construir o discurso oficial, legitimado pelo capital simbólico do grupo que a constituía. Contudo, o avanço do conhecimento médico sobre a doença e o surgimento de uma possibilidade terapêutica no final da década de 1980 levaram a uma alteração significativa da correlação de forças ao interior do espaço aids. Foram criados espaços autônomos de experts, e a participação dos demais grupos passou a ser mais pro forma. Segundo os entrevistados, a diversificação e especialização de comissões tornava mais ágil a discussão dos processos. 
Por outro lado, esse desmembramento em diferentes instâncias de decisão da política, de alguma forma, pulverizou o poder antes concentrado na Cnaids.

Além do aprofundamento da discussão acerca dos aspectos éticos para triagem sorológica do HIV e o plano de vacinas, o tema mais frequente nessas reuniões foi o projeto do acordo de empréstimo junto ao Banco Mundial. Mas “apesar do Projeto do Banco Mundial ter sido ponto de pauta, o tom da discussão era de apresentação do projeto e não de solicitação de apreciação, avaliação e intervenção da Comissão", o que reforça o caráter não deliberativo da comissão. (PROGRAMA NACIONAL DE DST E AIDS, 2003, p.38) O Programa Nacional e o Governo Federal assumiram a responsabilidade da negociação, cabendo à Comissão Nacional o papel de acompanhamento e avaliação da sua execução. (PROGRAMA NACIONAL DE DST E AIDS, 2003)

Segundo editorial do Boletim da Abia, a Comissão Nacional de Aids era

[...] o fórum de maior influência e responsabilidade sobre a formulação e o monitoramento das políticas brasileiras de controle da epidemia de HIV/aids no país [...] o que o país tem de melhor em matéria de especialistas da aids.(COMISSÃO..., 1993, p. 4)

A conjuntura começou a mudar a partir das discussões do primeiro acordo de empréstimo (AIDS I). Pelo caráter da negociação, essa permaneceu a cargo do poder executivo, envolvendo inclusive outras instâncias estatais como a Presidência da República, o Senado Federal, o Ministério do Planejamento, Orçamento e Gestão e o Ministério da Fazenda (BRASIL, 2005), estando fora do escopo das funções da Comissão. Contudo, o papel assumido anteriormente, com forte influência sobre a definição das estratégias técnicas a serem adotadas levou a uma disputa, encabeçada pelo representante da Abia, João Guerra C. Monteiro, pelo papel da Comissão. A Abia criticava a ineficiência da Cnaids no cumprimento das atividades que poderia e deveria desenvolver, principalmente no que tangia ao debate e a reflexão do processo de negociação com o Banco Mundial, de modo que o representante da Abia optou por se afastar da 
Comissão. ${ }^{102}$ (COMISSÃO..., 1993) A participação teria passado a ser meramente formal, na opinião de integrantes da Abia.

A gente acha que a Comissão estava totalmente inoperante, era início do projeto do Banco Mundial, enfim... Toda atenção era o grande projeto que se montava para o Banco Mundial. [...] Ela não conseguia mais influenciar as políticas de aids, não se dava ouvidos e atenção ao que se propunha, e então a Abia efetivamente resolve se afastar como uma maneira de denunciar essa inoperância, vamos dizer assim, da Comissão. $\left(\mathrm{E}_{33}\right)^{103}$

A necessidade de discussão do papel da Cnaids foi reconhecida por todos os seus membros, mas a posição colocada pela Abia do papel da comissão em relação ao Projeto do Banco Mundial não era consenso. Manifestaram-se sobre o posicionamento e/ou saída da Abia ${ }^{104}$ (BRASIL, 1994a, p. 116):

- Jair Ferreira (SES-RJ), que considerava inapropriado o comportamento da Abia, retirando-se antes da discussão das funções da Cnaids, sugerida pelo próprio representante da associação, e episódica a função relacionada ao projeto do Banco Mundial ${ }^{105}$ colocada no documento enviado pela Abia como função da comissão, propondo funções mais gerais;

- Lair Guerra, gestora do Programa Nacional, interpretou a sugestão da Abia para que a comissão não tivesse apenas um papel técnico, mas também político;

- Carlos Alberto Morais de Sá (Hospital Gaffrée e Guinle), Berenice Clemente (MEC) e Eliana de Paula Santos (SESAB) manifestaramse em apoio a Jair Ferreira com relação ao comportamento da Abia;

Ata da reunião da Cnaids de 15 de outubro de 1993.

103 Entrevista concedida por E33, psicólogo e diretor da Abia, no Rio de Janeiro, em 15 de junho de 2011.

104 Ata de reunião da Cnaids de 15 de outubro de 1993.

105

A Abia propunha, entre outras coisas, que a Comissão deveria "criar e impor mecanismos de controle social do Projeto do Banco Mundial”. (COMISSÃO..., 1993, p. 5) 
- Dirceu Greco (UFMG) assumiu posição de apoio à Abia no sentido de que uma comissão forte e independente poderia dar respaldo ao programa;

- Adelmo Turra (Gapa-RS) e Aurea Abbade (Gapa-SP) não concordaram com Jair Ferreira, mas afirmavam também não entender a posição da Abia com relação a sua saída da Comissão;

- Silvia Belluci (Centro Corsini) sugeriu discutir as funções sem considerar o documento da Abia.

Ou seja, a maioria daqueles que se manifestaram não viam motivo para a retirada da Abia da Cnaids, e alguns agentes, em especial aqueles do campo burocrático, exprimiram-se contrariamente ao posicionamento da Abia quanto às funções da Cnaids em relação ao Projeto AIDS I.

As discussões acerca do papel e funcionamento da Comissão Nacional levaram à incorporação de modificações na sua estrutura e composição (BRASIL, 1994b), influenciadas também pela Lei 8.142/90, que definiu os mecanismos de participação da comunidade na gestão do SUS. Foram agregadas novas competências e normalizou-se a participação social, através do acordo de como seria a representação das ONGs/Aids: um total de cinco representantes, dois da região Sudeste, dois das regiões Norte, Nordeste e Centro-Oeste e um da região Sul, escolhidos no Encontro Nacional de ONGs/Aids. ${ }^{106}$ (PROGRAMA NACIONAL DE DST E AIDS, 2003) A Comissão passou a ter as seguintes competências incorporadas na Portaria n. 1.028, de 31 de maio de 1994 (BRASIL, 1994b):

1. Participar na formulação e dar parecer sobre a política de prevenção e controle das DST/Aids;

2. Discutir diretrizes a serem observadas pelo Programa Nacional através dos Planos Operativos Anuais;

3. Identificar necessidades e coordenar a produção de documentos técnicos e científicos; 
4. Assessorar o Ministério da Saúde no desempenho das atividades do Programa Nacional de DST/Aids e participar do redirecionamento de estratégias;

5. Desempenhar papel de articulação política, mobilizando setores do governo e da sociedade civil para a luta contra a epidemia do HIV/aids.

Essa visão da Cnaids como uma instância de assessoria técnica é compartilhada por agentes dos diferentes espaços, contudo, alguns acreditam em uma perda de importância, relacionada a fatores como: o surgimento de outros comitês e comissões, que passaram a constituir espaços de discussões específicas; o aumento da capacidade técnica do quadro de funcionários do Programa Nacional; ou mesmo, os diferentes interesses e estratégias de permanência dos agentes no espaço aids e na própria comissão.

Eu acredito que não é que ela perde importância, mas eu acho que ela tem a função de capilarizar essas questões para outros espaços, [...] então, ela tem outro papel. Eu acho que são papeis diferenciados, mas que se complementam, mas eu não vejo como perdendo força política, acho que são papeis complementares e obviamente questões que inicialmente eram discutidas lá, ela passa a ter um foco pra ser discutido em um determinado espaço e aquela comissão é muito mais política, e as outras têm outras funções. $(\mathrm{E} 13)^{107}$

Com o aumento da capacidade técnica do programa, não só no sentido dos técnicos que estavam lá, mas no sentido de conseguir construir grupos específicos. Então, tinha que discutir, sei lá, os medicamentos antirretrovirais, se montava uma comissão específica, do consenso. Esses comitês e comissões setoriais vão enfraquecendo um pouco esse papel de excelência da Comissão Nacional, embora se

107 Entrevista concedida por E13, técnico do Departamento de DST, Aids e Hepatites virais, em Brasília, DF, em 2 de agosto de 2011. 
mantenha a Comissão Nacional como principal foco, principal estrutura, ela vai gradativamente perdendo esse poder de dizer sobre o Programa inteiro. (E1 ${ }^{108}$

Eu posso te dizer que antes a gente tinha voz. Tinha voz e tinha propostas. Todas as vezes que ia para uma reunião da Cnaids o Gapa sentava antes, discutia os temas, o que ia ser falado, como ia ser falado, a gente mesmo se questionava dias e dias naquilo, então, se levava quase que um documento pronto com vários pontos já discutidos e debatidos. Agora, pelo que eu sei, a coisa já vem pronta para assinar. Aíjá não éo que era. A única coisa que eu acho é que isso aconteceu por causa desse financiamento. Por que as pessoas ficaram? Primeiro porque o Aids-SUS é muito grande. Todo mundo quer viajar, todo mundo quer ficar em hotéis cinco estrelas, coisa que 90\% não sabe nem o que é um hotel [...], quer dizer, a orientação do que discutir não tem, mas tem hotel e isso te compra. Tem a passagem, tem a diária, que pra gente, você pode falar 100 reais não é nada, mas pra quem não recebe nada, vem de avião, volta, a pessoa fica assim boba. (E3)

Refletindo o aumento da complexidade das ações desenvolvidas pelo Programa Nacional e os avanços técnico-científicos, houve também uma ampliação dos temas pautados no período de 1994 a 1998, mas sem a atuação proativa em todos os temas como observado nos períodos anteriores. A prevenção, como já vinha acontecendo no final da década de 1980, estava dirigida a populações específicas. Começou a se discutir o uso do teste rápido, os avanços no tratamento antirretroviral e estratégias para sua utilização adequada, o fortalecimento das ações de descentralização, o aprimoramento da gestão, a questão dos direitos humanos em HIV/aids, os ensaios de vacina. A Cnaids teve participação ativa em dois momentos: a seleção dos Centros de Referência Nacional, onde pesou uma pressão da comissão para participar da operacionalização do Projeto AIDS I (16 de março de 1994); e na atuação junto ao Ministro para cobrar a compra emergencial de medicamentos (31 de maio de 1995). (PROGRAMA NACIONAL DE DST E AIDS, 2003) Nos dois casos, relacionado principalmente aos representantes de ONGs.

Entrevista concedida por E1, sociólogo e coordenador do Programa Nacional de DST/AIDS, em São Paulo, em 21 de junho de 2011. 
Com os avanços na terapia antirretroviral, entre 1999 e 2001, as discussões concentraram-se principalmente na assistência e nas ações de prevenção, as reuniões tornaram-se mais informativas das ações do Programa Nacional, havendo momentos nos quais foram discutidos temas emergentes como tecnologias reprodutivas e a não recomendação de um medicamento homeopático para tratamento da aids (o Canova). O processo de descentralização e a sustentabilidade das ações, temas que permeavam o projeto AIDS III, ficaram a cargo do Comitê Técnico Assessor de Gestores (Coge), ${ }^{109}$ criado em 2000. (PROGRAMA NACIONAL DE DST E AIDS, 2003)

Vale destacar que desde 1990, era o Conselho Nacional de Saúde a instância colegiada do SUS que tinha caráter deliberativo acerca da formulação de estratégias e no controle da execução da política de saúde, inclusive com relação aos aspectos econômicos e financeiros. (BRASIL, 1990) De modo que, embora tenha tido papel fundamental na definição do discurso oficial e na formulação da política de controle da aids na primeira década da epidemia, diversos fatos estabeleceram uma nova ordem no espaço aids brasileiro. Pode-se citar: os avanços do conhecimento médico e científico sobre a doença aids; o estabelecimento de medidas terapêuticas eficazes para o tratamento e controle da doença; a entrada de novos agentes nesse espaço de luta pela organização da resposta à epidemia de aids no país, como gestores estaduais e municipais e representantes da indústria farmacêutica; e a regulamentação das instâncias de participação popular na gestão do Sistema Único de Saúde nos anos 1990. Além disso, o advento do primeiro acordo de empréstimo colocou a aids como uma questão de governo. Esses fatos levaram à criação de novas instâncias de participação dos agentes de diferentes subespaços e à redistribuição e pulverização de forças entre essas instâncias. Essa reorganização define o espaço médico, técnico e burocrático nas subcomissões, separando-os

O Coge foi criado pela Portaria n. 992 do Ministério da Saúde, de 1 de setembro de 2000. Assim como a Cnaids, também é uma instância consultiva do Programa Nacional, tendo também o papel de promover a articulação entre os gestores dos três níveis de governo (federal, estadual e municipal) para a incorporação das ações de DST/Aids no processo de descentralização da saúde. 
do espaço militante ocupado pelas ONGs, que saíram enfraquecidas no seu papel político, havendo um deslocamento para o campo burocrático.

É interessante notar que as novas instâncias como Comitê de Vacinas e Comitê Assessor para Terapia Antirretroviral, seguem o modelo adotado pela própria Cnaids em várias situações em que havia a necessidade da discussão de questões específicas para as quais era constituída uma comissão de experts para a definição da posição oficial sobre assuntos específicos.

\section{O acesso universal aos ARV e o reconhecimento internacional}

O acesso universal à terapia antirretroviral no Brasil foi alcançado através de um processo para com o qual contribuíram agentes dos diferentes subespaços, em especial dos movimentos sociais. Quando o AZT foi aprovado pelo Food and Drug Administration (FDA), ${ }^{110}$ em 1987, em seguida, alguns pacientes no Brasil começaram a fazer uso através do contrabando do medicamento que ainda não possuía comercialização autorizada no país. Geralmente a compra era solicitada a comissários de voo da Varig ou da Vasp ou a pessoas que viajavam ao estrangeiro que traziam o medicamento em suas bagagens (E3; E12; E18; ${ }^{111} \mathrm{E}_{33}$ ), ou mesmo a importadoras. (E1; E18) Os compradores eram pacientes ou ONGs, como o Gapa-SP, mas o acesso ainda era muito restrito visto que o AZT ainda não estava disponível no Brasil. (SOUZA, 1987)

[...] a gente comprava desde o Zovirax, o AZT, tudo, mesmo comprando fora, mas a gente comprava ou ganhava. Uma pessoa do sul, uma vez, eu me lembro, nós tínhamos um paciente aqui, aí eles mandaram do sul para cá. Um mandava 15 comprimidos, outro mandava 10 [...] O que sobrava, vinha e a gente redistribuía. E o pessoal da Vasp, se eu não me engano, que ajudou muito trazendo de fora. [...]

Agência governamental americana responsável pela regulação e supervisão de alimentos, medicamentos, suplementos alimentares e outras substâncias.

111 Entrevista concedida por E18, matemático, fundador do Pela Vidda-SP, Membro Abia, diretor GIV e pesquisador Nepaids, em São Paulo, em 18 de junho de 2011. 
o Antônio Angarita que era o presidente. [...] ele dava essas passagens de cortesia para a gente. Quer dizer, a gente fazia os ofícios endereçados a ele, se era ele que dava ou não. [...] Pra a gente viajar para lá e para cá, e em uma dessas viagens, os meninos conheceram esses pilotos e aí esses pilotos que tinham viagens internacionais compravam e depois a gente dava dinheiro. Eu só sei que era em dólar. Aí a gente dava o dinheiro, eles compravam e repassavam para a gente ou para os pacientes que tinham grana. Era assim. (E3)

A normalização da venda do AZT no Brasil aconteceu a partir de 8 de outubro de 1987, sete meses após a aprovação pelo FDA nos EUA, quando a Divisão de Medicamentos (Dimed) publicou portaria ${ }^{112}$ com essa finalidade, questão que foi inclusive debatida na Cnaids. Mas o acesso ao medicamento ainda ficou restrito àqueles que tinham condições financeiras para arcar com o seu alto custo, numa época de hiperinflação e grande oscilação do câmbio. A divulgação da medida foi anunciada através de informe publicitário da indústria farmacêutica, publicado na Folha de São Paulo. No informe, o diretor da Wellcome no Brasil, Ricardo Lobo, falava como um agente do Estado, usando o nome da Dimed e do Ministério da Saúde. (Figura 9)

Ah, era um saco, porque era assim: a Glaxo [Wellcome] estava em Cotia, você tinha que comprar e eles vendiam em dólares, no câmbio do dia. E era uma época de inflação altíssima! Então você tinha que fechar o câmbio do dia, ir no banco, fazer boleto bancário, tudo formal, sabe? Mandava isso... Acho que era isso, boleto bancário ou cheque administrativo, só sei que era uma burocracia dessa, acho que boleto bancário. Eaí eles entregavam na sua casa. [...]. (E18)

Em 1989, no Encontro Nacional de ONGs/Aids (Enong) de Porto Alegre, foi elaborada a Declaração dos direitos do soropositivo (ANEXO A) que trazia entre outros pontos o direito de acesso à assistência e tratamento. A compra de AZT começou a ser realizada por alguns Estados de

BRASIL. Ministério da Saúde. Portaria $n^{\circ} 18$, de 6 de outubro de 1987 . Baixa instruções com vistas a normatizar a venda, em estabelecimentos, de medicamentos a base da substância azido timidina (AZT). 
FIGURA 9 - Transcrição do informe publicitário do laboratório Wellcome, publicado no jornal a Folha de São Paulo acerca do registro do AZT no Brasil, em 26 de novembro de 1987

\section{COMUNICADO SOBRE O “RETROVIR” (AZT) À CLASSE MÉDICA E ÀS AUTORIDADES SANITÁRIAS}

A Divisão Nacional de Vigiância Sanitária de Medicamentos (DIMED), do Ministério da Saúde, autorizou, por despacho do dia 9/11/87, o registro do "Zidovudine", sob a marca "Retrovir", também conhecido como "AZT". Esse medicamento, fabricado exclusivamente pelos laboratórios da Wellcome na Inglaterra e nos E. U.A., após anos de pesquisa, envolvendo 80 milhões de dólares, é o único tratamento atualmente disponivel em todo o mundo para pacientes portadores da Sindrome da Imunodeficiência Adquirida (AIDS). Com a aprovação do registro sanitário, deverão, agora, ser preenchidas as outras formalidades, necessárias à comercialização do produto no Brasil.

Enquanto isto, comunicamos:

1. No intuito de proporcionar aos pacientes brasileiros acesso ao medicamento pelo menor custo possivvel, estamos pleiteando junto às autoridades fazendárias federais e estaduais, a isenção dos impostos de importação (já concedida), IOF, ICM, PIS/FINSOCIAL

Do mesmo modo, estamos solicitando ao CIP - Conselho Interministerial de preços - a fixação do preço do "Retrovir" no mercado interno.

2. Colocannos à disposiçã̃o da classe médica e das auturidades saritárias unn serviço permarnente de informações técnicas a respeito do produto, sua aplicação e os resultados alcançados nos demais países que utilizam o "Retrovir".

3. Tão logo as autoridades concedam as demais isenções solicitadas a Wellcome estará em condições de fornecer "Retrovir" à classe médica, aos hospitais e outras entidades brasileiras credenciadas a atender portadores de AIDS.

4. Comunicamos, por fim que hospitais e outras instituiçõos interessados em importar diretamente o produto poderão fazê-lo pelo preço de importação uniforme, para todo mundo, de US\$188,00 por frasco de 100 cápsulas, $\mathrm{FOB}$, porto ou aeroporto de embarque na Inglaterra.

Para informações: Caixa Postal n 503 - CEP 06700 - Cotia - SP

Telex 1171729

Telefone (011) $492.3155-$ r. 300

RICARDO LÔBO

Diretor

Fonte: Wellcome (1987). 
forma incipiente, ${ }^{113}$ em especial devido a ações judiciais. A distribuição de medicamentos para doenças oportunistas acontecia desde 1988, de forma muito tímida, e a partir de 1991 teve início a distribuição de AZT. (PROGRAMA NACIONAL DE DST E AIDS, 2005)

\begin{abstract}
Então, eu comecei em 9o. Porque eu comecei em outubro, final de outubro, porque eu tive uma queda um pouco de CD4. [...] eu tive leucoplasia pilosa, então um amigo disse 'Ah, você tem que começar!'. E depois de um tempo me inseriram, porque eu não sei se eu estava, porque eu não tinha aids, felizmente eu não desenvolvi, mas não sei se eu tinha direito, mas eu comecei a tomar igual pelo serviço público. (E18)

[...] não tinha uma regularidade assim, ou logística de compra e de entrega, não era uma coisa muito regular. Mas em 1991, que até foi na breve passagem do Eduardo Côrtes no Programa que se começou, se aumentou o fornecimento de AZT. [...] Depois, em 1992, quando o Eduardo saiu, já se manteve. (E3O)
\end{abstract}

A distribuição de medicamentos ARV pelo Ministério da Saúde não era uma proposta inicial, nem em 1988, na gestão de Lair Guerra, nem do presidenciável Fernando Collor de Mello em 1989, que em consulta realizada pelo Gapa junto a cinco dos candidatos a presidente, considerava que a aquisição do AZT deveria ser encargo dos doentes, das empresas, das instituições privadas de assistência e de fontes não exclusivamente governamentais. (CANDIDATOS..., 1989; DROGA..., 1988) Mas pressionado pela imprensa, o Ministro Alceni Guerra terminou cedendo à aquisição de AZT pelo governo em 1991.

Apesar da disponibilidade de medicamentos como AZT, pentamidina e ganciclovir desde àquele momento, conforme noticiado na imprensa e confirmado através de relatos de usuários e profissionais, o tratamento apenas com o AZT, ou monoterapia ainda era pouco eficaz. (COHEN, 1993; SELIGMANN et al., 1994) nas $7 \%$ dos pacientes. (PROGRAMA NACIONAL DE DST EAIDS, 2005) 
[...] o AZT matava antes da doença. Os pacientes me diziam assim 'Eu não quero morrer com esses remédios. Meus amigos estão morrendo.' Eles ficavam verdes de tomar aquele negócio. E morriam logo. Hoje eu sei com mais certeza ainda que muitos poderiam ter vivido mais tempo, até chegar o momento de usar uma coisa que não matasse, que o AZT era usado assim de tonelada e eles morriam rapidamente. [...] se um filho meu tivesse uma doença que o medicamento matasse antes da doença, eu não ia deixar ele tomar. E aí eles me procuravam porque eu não obrigava a tomar. E aífoi que eles me mandaram para o CRM, fiquei uns 7 anos nessa história, porque eu não dei o AZT. Eles não pararam nem quando foi proibido. Foi proibido usar o AZT naquele modelo. Você tem que usar uma dose dez vezes menor. [...] E isso provocava uma anemia profunda e eles morriam mais rapidamente. (E31)

Assim, começou a ser aplicada a terapia combinada, geralmente, associando duas drogas - AZT+ddI ou AZT+ddC.

A partir de 1994, com o financiamento do Banco Mundial, foram criadas diversas assessorias jurídicas nas ONGs, seguindo o modelo do Gapa. Foram essas assessorias e, em especial, a assessoria do Gapa, através da advogada Áurea Abbade, que, em 1996, iriam promover as ações de demanda de medicamentos para portadores de HIV/aids. (PROGRAMA NACIONAL DE DST E AIDS, 2005)

[...] quando começou a história da judicialização da saúde [...], era o Guedes o secretário, eu coordenava os Institutos de Pesquisa, o CRT era da minha coordenação. Então as ações judiciais para comprar esses medicamentos que não estavam no consenso, caiam todas na minha mesa. Evinham todos em sua maioria assinados pela Áurea $[\ldots]$... (E19) $)^{114}$

No governo Fernando Henrique Cardoso (FHC), ${ }^{115}$ em março de 1995, a Portaria n. 21 da Secretaria de Atenção à Saúde do Ministério da Saúde, garantiu a todos os pacientes o acesso à AZT, didanosina (ddI),

Entrevista concedida por E19, médico membro do Comitê de Vacinas do Programa Nacional de DST/Aids, em Salvador, em 13 de maio de 2011.

115 Foram Ministros da Saúde do governo FHC: Adib Jatene (janeiro/1995 a novembro/1996); José Carlos Seixas (novembro/1996 a dezembro/1996); Carlos César de Albuquerque (dezembro/1996 a março/1998); José Serra (abril/1998 a fevereiro/2002). 
pentamidina, ganciclovir, fluconazol e anfotericina B. Mas foi a partir de 1996, na terceira fase da história dos antirretrovirais, com os inibidores da protease, que de fato surgiram mais opções de tratamento, medicamentos que permitiram melhores desfechos clínicos e aumento significativo da sobrevida dos pacientes, uma verdadeira revolução no tratamento da aids. (SCHEFFER, 2008)

Enquanto a imprensa divulgava os avanços na terapia, ainda em 1995, começaram a acontecer as manifestações em espaços públicos, promovidas principalmente pelas ONGs/Aids, mas também por artistas, em iniciativas mais individuais, exigindo a distribuição de medicamentos pelo Estado. (PROGRAMA NACIONAL DE DST E AIDS, 2005)

Em Campinas/SP, no dia 14 de agosto de 1995, 40 manifestantes, entre portadores do HIV e familiares, ocuparam o paço municipal para reivindicar o coquetel. No dia 26 de setembro, inúmeras ONGs protestaram contra a falta dos novos medicamentos jogando litros de uma mistura que simulava sangue em frente às Secretarias Estadual e Municipal de Saúde de São Paulo. A avenida Paulista, em São Paulo, foi palco de grande ato no dia $1^{\circ}$ de dezembro do mesmo ano, com dezenas de corpos estendidos pelo chão.

Atos semelhantes pipocavam país afora e extrapolavam o âmbito dos grupos organizados. O estilista carioca Luiz de Freitas, por exemplo, colocou no final de seu desfile 15 portadores do HIV em protesto pelo preço e dificuldade de acesso aos medicamentos. Já o cenógrafo José Roberto de Godoy fez um protesto no Pavilhão da Bienal, em São Paulo. Nu, em meio a caixas de medicamentos, protestou contra a falta dos anti-retrovirais. (PROGRAMA NACIONAL DE DST E AIDS, 2005, p. 22-23)

Desde o surgimento do AZT, Betinho já defendia a garantia de tratamento pelo Estado aos portadores de HIV/aids. Apesar de não curar a aids, considerava que o AZT dava uma perspectiva de prolongamento da vida, e que era "um dever da sociedade brasileira dar ao aidético brasileiro essa chance" e teve papel preponderante na definição da política de acesso universal aos medicamentos antirretrovirais. (SOUZA, 1987) 
Com todos os avanços que se obtiveram no tratamento da aids, Betinho enviou duas cartas ao Presidente Fernando Henrique Cardoso, uma em janeiro e outra em fevereiro de $1996,{ }^{116}$ pedindo medidas mais efetivas. Em ambas, o presidente da Abia relatava suas críticas ao enfrentamento da epidemia no país, destacando a não consolidação do Programa Nacional, mesmo com o projeto do Banco Mundial, o alto custo de preservativos no país e a dificuldade para acesso aos medicamentos oferecidos pelo ministério, além do preço elevado dos medicamentos para aquisição pelos pacientes. Nos debates do seminário intitulado “Tratamento e Assistência em HIV/aids", promovido pela Abia, nos dias 25 e 26 de março de 1996, além dos avanços científicos, destacava-se a não prioridade do tratamento e da assistência no projeto do Banco Mundial, a dificuldade de acesso aos medicamentos oferecidos pelo Ministério da Saúde, a inexistência de uma política de medicamentos no país e Betinho criticou, duramente a periodicidade das campanhas, dizendo que "Para o governo, a epidemia é um festejo carnavalesco, como se fora do carnaval ninguém pegasse aids no Brasil”, ponto de vista crítico de esquerda sobre a política nacional. (CORRÊA, 1996, p. 7)

A apresentaçãonaXI Conferência Internacional de Aids de Vancouver, em julho de 1996, por David Ho e Martin Markowitz, dos resultados obtidos com um coquetel de três drogas, contendo um inibidor da protease, (BOUER, 1996, p. 16) associada à decisão favorável da Justiça de São Paulo à ação impetrada pela advogada do Gapa, Áurea Abbade, em nome da professora Nair Soares Brito para fornecimento dos medicamentos neodecapeptil, saquinavir e epivir pelo Estado, serviram de impulso para novas ações judiciais demandando fornecimento de inibidores da protease. (FELTRIN, 1996; MARTINS, 1996) Até aquele momento, a única cidade do país que fornecia por conta própria o coquetel era a cidade de Santos, no estado de São Paulo. (MARTINS, 1996)

A Folha de São Paulo do dia 13 de julho de 1996 trazia na sua sessão tendências/debates a questão "A importação de remédios contra a aids deve ser prioridade do Ministério da Saúde?”, para a qual havia três respostas,

Estas cartas foram publicadas no Boletim da Abia, n. 31, p. 15-16, jan./abr. 1996. 
que correspondiam aos argumentos dos grupos a favor, que consideravam um direito do portador de HIV/aids; daqueles que defendiam uma administração mais racional dos recursos; e dos que estavam contra a medida, que consideravam discriminar outras enfermidades:

a. A estratégia era defendida pelo médico infectologista David Everson Uip, que destacava que o custo médio elevado de $\mathrm{R} \$$ $1.000,00$ por paciente/mês, representava um investimento da ordem de $\mathrm{R} \$ 143$ milhões, mas justificados pelo aumento, qualidade e dignidade da sobrevida do paciente, bem como pela redução das hospitalizações e de outros medicamentos necessários, um ponto de vista clínico e individual;

b. A administração racional de recursos era expressa na fala de Luiz Roberto Barradas Barata. O médico sanitarista e secretário interino de saúde do estado de São Paulo no momento da reportagem, pontuava os critérios epidemiológicos como magnitude e transcendência da doença e a eficácia do tratamento como razões que justificavam a adoção da estratégia. Mas, na sua opinião, a realidade financeira da saúde pública não permitia um gasto da ordem de $\mathrm{R} \$$ 20.000,00 por paciente/ano, argumentos técnico-científicos;

c. E o médico, deputado federal pelo PSDB-SP e diretor-presidente da Blue Life Assistência Médica, Ayres da Cunha, argumentava contra a estratégia, considerando que a questão da aids era tratada de forma paternalista e que a distribuição gratuita de medicamentos para a aids seria uma medida discriminatória e ilegítima com os pacientes de outras patologias. Posição que podia estar representando os interesses da medicina supletiva pelos recursos do SUS.

Essas concepções aparecem na fala de alguns entrevistados, seja refletida na sua própria concepção ou no relato de posicionamentos com os quais não concordavam, porém, com maior abrangência, relacionada não apenas aos medicamentos, mas à toda a questão da assistência à saúde. Entre eles, a fala pareceu mais polarizada entre a justiça para os doentes e a discriminação contra outras doenças, não no sentido de negar o direito 
de acesso a medicamentos aos portadores de HIV/aids, mas de garantir o direito à assistência à saúde aos portadores de todas as enfermidades. Esse último argumento aparece principalmente na fala daqueles que saíram do espaço aids ou que transitaram por outros espaços do setor saúde. Outra posição destacada por um dos entrevistados era uma posição homofóbica.

[...] eu acho que isso é uma obrigação do Estado, [...] existia muitas posições contrárias, que isso era um absurdo num país onde você não tinha as questões mínimas de garantia de direitos, por que é que tinha que dar remédio pra pessoas promíscuas. Você ouvia isso de políticos. (E13)

[...] eu me lembro de médicos que também atendiam tuberculose e diziam: 'não, porque meus pacientes de tuberculose não tem remédios, porque só tem remédios para aids'. Não tem nada a ver uma coisa com a outra. (E18)

[...] Eu acho que a Política Nacional de Aids ela significa para o SUS um exemplo de como a gente deve trabalhar para as outras doenças. [...] Esse exemplo deveria ser pego, para a gente trabalhar com as outras, principalmente, com as negligenciadas. [...] eu acho que as outras tem que se igualar para que a gente possa ter um resultado parecido. (E11)

[...] para a política da aids, eu acho que o que o público em geral necessita éo quejá existe. É atendimento quando e onde eles precisam. Você não vêum indivíduo com HIV rodando por aídizendo que não foi atendido. Isso éuma coisa inédita. Porque você vê gente com lepra dizendo que não foi atendido. [...] Então para aids eu não sinto necessidade de mais do que já existe em termos operacionais. [...]. (E31)

Diante dessa diversidade de pontos de vista, cabe indagar porque prevaleceu aquele da universalização do tratamento.

O Programa Nacional foi considerado por alguns agentes como exemplo de que o SUS pode dar certo, ou seja, exemplo de política integral, universal, e inclusiva, que aproximou grupos minoritários como homossexuais, profissionais do sexo, usuários de drogas dos serviços de saúde. (Quadro 9) Mas pelo menos uma fala deixou claro que os usuários 
portadores de HIV/aids têm acesso a serviços especializados de saúde e suporte comunitário que não são acessíveis à qualquer pessoa. A excelência da assistência prestada pelos centros de referência estaria, segundo esse relato, restrita aos soropositivos, excluindo inclusive populações vulneráveis, evidenciando assim um enfoque no tratamento da doença e a secundarização da prevenção da aids, por um lado, e por outro, das limitações das demais políticas ou de outras políticas sociais, ou seja, a política nacional de controle da aids é vista como uma exceção.

[...] se você tem assim um problema de doença infectocontagiosa, você vai lá [Centro de Referência] e não pode ser atendido. Aí pergunta, você é positivo? Aí vocêfala, não sou. Já aconteceu duas vezes comigo. Porque são serviços de primei$r a$, porque tem infectologistas que em geral nos serviços não tem, aí você vai lá e vocênão épositivo. E por outro lado também eu encontrei pobres que se nãofossem positivos não seriam tão bem assistidos, como são tratados os pobres. Eisso vai desde serviços de saúde a associações comunitárias que dão suporte. Eu acompanhei uma ONG de usuários de drogas, 35 usuários de drogas em Osasco, ealgumas pessoas falavam: 'A sorte é que eu tive HIV. Porque agora eu tive esse suporte, tenho esse suporte comunitário'. Era população de rua, viviam nas ruas sem estrutura nenhuma, aíjá tinham casa, tinham moradia... (E25) ${ }^{117}$

Outro aspecto destacado pelos entrevistados foi a discussão da política com agentes dos diferentes subespaços sociais, em especial o espaço militante, ou seja, a sua importância como exemplo de possibilidade dos movimentos sociais interferirem numa política. Da mesma forma, na França, a luta pelo controle à epidemia da aids teve um cunho de contestação social, uma forma de expressão política, diferindo da representação de uma sociedade solidária, generosa e unida, observadas nos casos dos movimentos de luta contra outras doenças, como tuberculose e câncer, por exemplo, levando à organização de um movimento estruturado por associações militantes em defesa das pessoas atingidas e ameaçadas pela epidemia. (PINELL, 2010; PINELL et al., 2002) de maio de 2011. 


\begin{tabular}{|c|c|}
\hline Concepção & Trecho \\
\hline \multirow[t]{3}{*}{$\begin{array}{l}\text { Como modelo de política integral e } \\
\text { universal, estruturante do SUS e sem } \\
\text { discriminação }\end{array}$} & $\begin{array}{l}\text { A política da aids, ela significa que o SUS pode dar certo, porque a política da aids, ela } \\
\text { promove todas essas questões da equidade, da intersetorialiade, ela é universal, então } \\
\text { não tenha duvida de que ela é a prova de que o SUS dá certo. (E13) }\end{array}$ \\
\hline & $\begin{array}{l}\text { [...] Não tem nada de bom na aids. Mas o bom da aids foi que a aids mostrou um } \\
\text { SUS de altíssimo nível, com todos os princípios garantidos é possível, mesmo com } \\
\text { todos os problemas que a agente está falando aqui. Ele realizou o SUS de um jeito } \\
\text { interessante, tirou o véu da hipocrisia, da sexualidade escondida. Eu acho que ampliou } \\
\text { a generosidade pra com as pessoas homossexuais [...] Eu acho que é um bom exemplo. } \\
\text { Com toda suas limitações. (E32) }\end{array}$ \\
\hline & $\begin{array}{l}\text { [...] eu sempre digo que a aids talvez tenha sido a primeira experiência em que } \\
\text { a gente conseguiu concretizar os ideais do SUS. } 0 \text { acesso universal, a assistência } \\
\text { multiprofissional, integral e a participação da sociedade. Um envolvimento mesmo } \\
\text { visceral da sociedade, das pessoas afetadas. (E30) }\end{array}$ \\
\hline \multirow[t]{2}{*}{$\begin{array}{l}\text { Como exemplo da possibilidade dos } \\
\text { movimentos sociais interferirem numa } \\
\text { política }\end{array}$} & $\begin{array}{l}\text { A aids [...] é um dos maiores exemplos de aglutinação do movimento social. [...] Se } \\
\text { tu pegar, por exemplo, a organização dos diabéticos, a luta não é travada no campo } \\
\text { político. Ela é muito mais no campo da assistência, das condições de vida, a da aids não, } \\
\text { ela vem do campo político, porque ela perpassa as questões apenas da doença e entra } \\
\text { numa seara política, a partir do enfrentamento do preconceito, da discriminação, das } \\
\text { condições de vida, do direito do sujeito ser quem ele é, perpassa por tudo. Ea partir } \\
\text { disso se faz a política, se faz um movimento político, se faz um enfrentamento com a } \\
\text { sociedade, com as instituições, com a igreja, com o estado, enfim. Então, a aids ela vai } \\
\text { mexer com todo o sistema de saúde. [...]ela vai forçar o sistema de saúde a ter uma } \\
\text { outra lógica. E ai a aids, ela ajuda na questão da formação do controle social. } 0 \text { que ela } \\
\text { provoca de ódio e de raiva é muito grande. Mas que ela contribui, ela contribui. (E12) }\end{array}$ \\
\hline & $\begin{array}{l}\text { [...] eu diria que o programa de aids, conforme ele se passou no Brasil, colaborou muito } \\
\text { para construção do SUS, do ponto de vista do controle social. Não esse controle social } \\
\text { que nós vemos dos conselhos, sabe. É lamentável, porque hoje em dia, nós vamos no } \\
\text { interior,[...] e são conselhos que na realidade são apêndice do poder executivo. [...] } \\
\text { eu acho que o programa de aids, ele teve sua missão importante enquanto programa } \\
\text { vertical, não tenha dúvida, porque isso ajudou muito a construir normas e implantar } \\
\text { procedimentos. Mas cada vez mais nós vemos como um processo horizontalizado que } \\
\text { faz parte da rede pública, mas tem que estar presente, como acontece com vários } \\
\text { programas, ou com várias abordagens. (E27) }\end{array}$ \\
\hline \multirow[t]{2}{*}{$\begin{array}{l}\text { Como exemplo de política inclusiva de } \\
\text { populações minoritárias e discriminadas } \\
\text { pelo SUS }\end{array}$} & $\begin{array}{l}\text { Sem dúvidas, eu acho que representa desafios, porque houve também, claro, de ser } \\
\text { adaptados, por exemplo, serviços especializados tiveram que ser criados, hospitais-dia } \\
\text { tiveram que ser criados. [...] atender e atender bem populações que estavam longe do } \\
\text { serviço de saúde. Atender à mulheres profissionais do sexo. Os profissionais de saúde } \\
\text { não estavam acostumados com isso. Discutir sexualidade com pessoas, fazer pré- } \\
\text { aconselhamento, pós-aconselhamento, eu acho que tudo isso foi um longo aprendizado } \\
\text { e, mesmo assim, eu acho que ainda há muitas resistências à atender pessoas que são } \\
\text { consideradas diferentes. Então, atender travestis não é algo trivial no SUS. (E16) }\end{array}$ \\
\hline & $\begin{array}{l}\text { [...] acho que o grande contributo da aids foi ter colocado na mesa as necessidades } \\
\text { de saúde de diferentes populações que se encontravam afetadas pela epidemia pra } \\
\text { dentro do contexto do sistema único de saúde, quer dizer, trazer os gays, trazer as } \\
\text { prostitutas, trazer usuários de drogas injetáveis pro contexto do sistema único de saúde } \\
\text { e colocar isso em evidencia, pautando ainda a questão da equidade, é extremamente } \\
\text { importante. (E17) }\end{array}$ \\
\hline
\end{tabular}

Fonte: Elaborado pela autora. 
Mesmo com as mudanças de governo e de ministros, Lair Guerra permaneceu na coordenação do Programa Nacional até 1996, quando sofreu um traumatismo craniano decorrente de um acidente de carro na volta de um congresso de aids realizado em Recife, momento em que o Programa Nacional foi assumido por Pedro Chequer, seu adjunto.

A relação do PN com a Abia, em especial com seu presidente, Betinho, mudou, seja em função da sua relação com o novo diretor, com quem tinha maior proximidade e disposições políticas semelhantes, seja devido aos avanços na política de aids no país.

Ele tinha uma birra com a Lair, havia uma querela entre ele e a Lair antiga. E comigo não tinha, porque ideologicamente nós tínhamos coisas em comum, ou quase tudo em comum. E no final, a gente se entendia muito bem. (E27)

O projeto de lei no 158/1996 (ANEXO B), de autoria do senador José Sarney, que propôs o acesso universal aos medicamentos para tratamento da aids, representava os anseios de diversos grupos, em especial da sociedade civil organizada, que já vinha promovendo mobilizações nesse sentido. Contudo, o projeto teria resultado de uma articulação entre o sociólogo Betinho, o médico sanitarista e deputado federal pelo Rio de Janeiro, Sérgio Arouca e o ex-ministro da saúde e ex-deputado Carlos Sant'Anna que à época era chefe de gabinete do senador José Sarney e teria escrito a minuta do projeto.

O Sarney, elefoi procurado pelo próprio Betinho. (E6)

Quem redigiu o projeto foi Carlos Sant'Anna, que era assessor do Sarney. (E9)

A ideia original foi de Sérgio Arouca, provavelmente conversando com Betinho. Porque Arouca era deputado pelo Rio. Aílevou, como se davam muito bem Arouca e Carlos, ele foi presidente da Fiocruz quando Carlos estava lá [no Ministério da Saúde] [...] Aí eles se conversavam, se apoiavam. Então quando chegou nessa lei, Carlos sabia escrever lei muito bem. [...] Todo mundo reconhecia isso. Então muitos deputados, e Arouca também foi lá, levavam para ele para ver a forma, o processo legislativo, aquele negócio todo. Edepois, a forma como caminhar no campo minado 
que éa Câmara para você chegar promulgar uma lei. A câmara e o senado, os dois. Então ele viu tudo e bolou com Carlos uma estratégia que disse assim: 'Se vocêdeixar Sarney apresentar provavelmente é mais forte.' Mas a ideia original foi de Arouca. E foi de Arouca trazido do Rio, que eu acho que foi Betinho. [...] Quem levou para Carlos a proposta, a ideia inicial foi Arouca, Carlos trabalhou na melhoria da proposta com Arouca [...] Então eu imagino que nesse desenho da estratégia para fazer com que o projeto de lei, chegasse a câmara, Carlos deve ter negociado com Arouca, que isso seria através de Sarney. Então Carlos entrou nisso no sentido de sensibilizar Sarney para fazer lá. Mas a ideia original foi essa. (E10)

A exposição de motivos do projeto de lei falava do direito constitucional à saúde e da questão humanitária, bem como das notícias da XI Conferência Nacional de Aids, realizada em Vancouver. A aprovação da contribuição provisória sobre a movimentação financeira (CPMF) era apresentada como um aporte orçamentário que poderia fazer frente a essa nova despesa, bem como ponderava acerca da possível redução de gastos com a assistência a doentes, relacionadas à infecções oportunistas e internações, e que o Brasil, como um país de grandes riquezas, não poderia deixar de garantir a esperança e condições de vida aos indivíduos acometidos pela pandemia da aids. (ANEXO B)

A tramitação do projeto no poder legislativo foi rápida: da apresentação do projeto à sua aprovação transcorreram 90 dias. Não houve polarização dos debates, todos os parlamentares que se manifestaram fizeram-no a favor do direito à saúde e da garantia de tratamento aos portadores de HIV/aids, haja vista que o projeto tratava de uma reafirmação dos direitos constitucionais, ainda que houvesse oposição de alguns deputados, como percebido na fala do deputado Ayres da Cunha ao jornal Folha de São Paulo. A votação da proposta na Câmara dos Deputados (PL n. 2.375 , 1996) foi adiada por requerimento do líder do governo, o deputado Benito Gama (PFL-BA), ainda que sob a discordância de alguns deputados como Fernando Gabeira (PV-RJ), Eraldo Trindade (PPB-AM), Alexandre Cardoso (PSB-RJ), Sérgio Miranda (PcdoB-MG), Matheus Schmidt (PDT-RS) e Paulo Rocha (PT-PA) que se opuseram à retirada da votação da pauta. A justificativa para o adiamento estava relacionada 
principalmente à alocação de recursos, uma vez que a despesa não estaria prevista, havendo necessidade de adequação do orçamento pelo governo federal. Nova votação aconteceu no dia 14 de outubro de 1996, apenas cinco dias depois. O relator, o deputado Arnaldo Farias de Sá (PTB-SP), propôs mudanças redacionais que foram revisadas no retorno ao Senado e incluiu a responsabilidade de todos os gestores do SUS (união, estados e municípios) no financiamento, assim como restrições socioeconômicas para a distribuição dos medicamentos e a priorização de pacientes em internação hospitalar. ${ }^{118}$ (AZEVEDO, 2010)

No retorno ao Senado, o relator, senador Lúcio Alcântara (PSDB$\mathrm{CE})$, manteve o texto original da PL 158 e rejeitou as restrições de caráter socioeconômico e a priorização de pacientes internados propostos pelo substitutivo da Câmara dos Deputados, considerando as restrições impostas inconstitucionais, haja vista a saúde tratar-se de um direito de todos e um dever do Estado, e que a tendência era de estímulo a políticas de desospitalização, não havendo recomendações na literatura médica de internamento para o uso de antirretrovirais. O cofinanciamento pelos gestores do SUS foi acatado, modificando o art. $2^{\circ}$ da PL 158. A redação final foi aprovada em plenário, correspondendo ao texto da Lei $n^{\circ}$ 9.313, sancionada em 13 de novembro de 1996 pelo presidente Fernando Henrique Cardoso. (AZEVEDO, 2010)

Ainda que de fato tenha apenas ratificado direitos constitucionais, a nova lei reforçou a luta dos portadores de HIV/aids e das ONGs/Aids pela garantia de acesso ao tratamento, levando inclusive a uma situação diferenciada do acesso aos medicamentos antirretrovirais em relação ao acesso a outros medicamentos no SUS, como já destacado anteriormente.

O passo seguinte foi o estabelecimento de protocolos para a prescrição dos medicamentos, a organização de fluxos e divisão de responsabilidades entre municípios, estados e união; à garantia do acesso aos medicamentos e à sustentabilidade da estratégia.

O parágrafo $3^{\circ}$ do substitutivo proposto pela Câmara dos Deputados (BRASIL, 1996a) dizia: "A distribuição gratuita dos medicamentos observará critérios sócio-econômicos, conforme regulamento, e dará prioridade aos pacientes em regime de internação hospitalar". 
Em dezembro de 1996, foi criado o Comitê Técnico Assessor para Terapia Antirretroviral que elaborou o guia de orientações terapêuticas em HIV/aids. Esse Comitê era composto pelos médicos Pedro Chequer (Dirigente do PN DST/Aids), Celso Ferreira Ramos (Prof. Doenças Infecciosas e Parasitárias UFRJ), Geraldo Duarte (USP - Ribeirão Preto), Heloísa Helena de Souza Marques (Médica pediatra do Hospital das Clínicas da USP), Helvécio Bueno (Assessor do PN DST/Aids), João Silva de Mendonça (Diretor do Serviço de Moléstias Infecciosas do Hospital do Servidor Público Municipal de São Paulo), Marinice Coutinho Midlej Joaquim (Técnica da Coordenação Materno-infantil), Norma de Paula Motta Rubini (Unirio), Rosana del Bianco (Chefe da Unidade de Assistência do Programa Nacional de DST/Aids), Sandra Maria Martin (Assessora da Unidade de Assistência à Saúde do Programa Nacional de DST/Aids) e Valdiléa Gonçalves Veloso dos Santos (Fiocruz). Em 1997, foi realizada a primeira revisão, tendo como produto o consenso para terapia antirretroviral para adultos e adolescentes infectados pelo HIV/aids.

A implantação da estratégia universal de acesso a antirretrovirais aumentou o registro de casos em torno de 39\% em 1996. Segundo declaração do Coordenador do Programa Nacional de DST/Aids, Pedro Chequer “[...] Muitos pacientes que se tratavam com médicos particulares e não notificavam a doença para as autoridades sanitárias tiveram de se identificar.” (FALCÃO, 1997, p. 6) Os mandatos judiciais que obrigavam o Estado a fornecer medicamentos fora das especificações e dos critérios estabelecidos no consenso terapêutico ampliavam o acesso, implicando em novos custos. (FALCÃO, 1997) Contudo, houve uma redução dos gastos com internação, em torno de 40\% no CRT de São Paulo e 35\% no Hospital Emílio Ribas, e no uso de medicamentos para infecções oportunistas, para o ganciclovir houve uma redução de $20 \%$. Um paciente em uso de antirretrovirais custava cerca de $\mathrm{R} \$ 10.000,00$ por ano, $50 \%$ menos que se ficasse doente. (MARTINS; TOSTA, 1997)

Um dos principais problemas para implantação doacessouniversal era a falta de controle logístico dos estoques de medicamentos - diversos pacientes pegavam medicamentos em diferentes unidades, desabastecendo a rede. (FALCÃO, 1997) Para organizar a distribuição dos medicamentos e 
acompanhar os resultados, Pedro Chequer, epidemiologista com experiência na elaboração de sistemas de informação em saúde, ${ }^{119}$ coordenou a elaboração de dois sistemas de informação para o Programa Nacional de DST/ Aids: o Sistema de Controle Logístico (Sisclom) e o Sistema Informatizado de Controle Laboratorial (Siscel). O Sisclom foi elaborado para controle na distribuição de medicamentos, permitindo uma visão global do percurso do medicamento até a sua distribuição e o controle do estoque, e o Siscel foi criado para acompanhamento dos exames laboratoriais. Uma outra iniciativa seria a implantação de um “cartão aids" para identificação dos portadores acompanhados no SUS, mas que não foi adiante devido à intenção do Ministério da Saúde de implantar o cartão SUS. ${ }^{120}$

O compromisso com a manutenção do acesso universal era assumido não apenas pelo Ministério da Saúde como pelo Palácio do Planalto. (SÃO NECESSÁRIOS..., 1997)

A aprovação da lei de acesso universal a medicamentos para portadores de HIV/aids impôs importantes transformações no espaço aids brasileiro: a crítica mais ácida das ONGs com relação à política quase que desapareceu, sendo a principal demanda o cumprimento do estabelecido na legislação, em especial o acesso a medicamentos; o Programa Nacional passou a ter uma posição dominante e reconhecimento internacional.

A luta pela sustentabilidade da estratégia de acesso universal aos antirretrovirais contribuiu também para a regulamentação dos medicamentos genéricos no país e influenciou o posicionamento político

Quando esteve no Centro Nacional de Epidemiologia (CENEPI), Pedro Chequer participou da criação do Sistema de Informação de Agravos de Notificação (Sinan).

120 "E em seguida nós bolamos o cartão, [...] eu tinha um exemplar desse cartão, era um cartão para paciente de aids. Porque mesmo com o Siclom posto e funcionando precariamente, começamos com pouco serviço, depois com mais 120 serviços, 150 serviços, hoje não sei quanto está, acho que está em 500, algo assim. Mas tínhamos um problema que surgia a partir do debate com o campo ou com as redes de pessoas vivendo, pacientes que moravam em São Paulo, por exemplo, que estavam na Bahia, como é que recebia o remédio? Ou se acabasse o remédio, ou se tivesse que permanecer? Ai nós bolamos um cartão, era um cartão que ia ter um chip que o paciente ia no Siclom, debitava na 'conta' dele. O Ministério ficou enciumado, a SAS era inimiga. Werneck, Dr. Werneck. Nós tínhamos o ministro que morreu, o gaúcho [Carlos César Albuquerque]. [...] Nós chegamos a ter o nosso cartão, em 1997, [...], o cartão aids. E lançamos oficialmente e tudo mais, mas aí foi vetado! 'Não... Vai ter o cartão SUS, o cartão SUS dá conta de tudo'. Tudo bem, infelizmente, estão patinando até hoje.”(E27) 
internacional do país haja vista a disputa com a indústria farmacêutica internacional pela redução dos preços dos medicamentos antirretrovirais. (LOYOLA, 2008) Essa foi umas das mais importantes disputas que aliou médicos sanitaristas, pesquisadores, agentes do campo burocrático e usuários contra a indústria farmacêutica.

Pedro Chequer saiu da direção do Programa Nacional em março de 2000 , quando foi convidado para ser representante do programa conjunto das Nações Unidas sobre HIV/aids (Unaids) no Cone Sul. Assumiu a direção do programa o médico Paulo Roberto Teixeira, primeiro coordenador do Programa Estadual de São Paulo, que permaneceu na função até 2003, quando foi para a Direção do Programa de Aids da OMS.

Foi durante a gestão de Paulo Teixeira que o Programa recebeu o prêmio Bill e Mellinda Gates, no valor de um milhão de dólares, considerado como a ação de saúde pública mais relevante de 2002. O prêmio foi investido em projetos de casas de apoio a portadores de HIV/aids. Foi também na sua gestão que na busca pela sustentabilidade do acesso a medicamentos antirretrovirais, foi proposta pela primeira vez pelo governo brasileiro a quebra de patentes. (ABBADE; BAIÃO, 2010)

A incorporação constante de novas tecnologias sempre implicou em aumento dos custos do tratamento para a aids. Entre o registro de um medicamento e a sua inclusão no consenso, ações judiciais eram movidas por pacientes que necessitavam da nova droga, obrigando o SUS a fornecer antirretrovirais não disponíveis na rede pública, às vezes medicamentos ainda sem registro no país. (SCHEFFER, 2008)

A sustentabilidade da estratégia de acesso universal passou a ser uma prioridade. O Ministro da Saúde José Serra decidiu centralizar e ampliar a produção nacional de antirretrovirais genéricos e ameaçou utilizar licenças compulsórias para produzir medicamentos patenteados. (NUNN, 2009) Laboratórios estatais como o Instituto de Tecnologia em Fármacos (Farmanguinhos) e Fundação para o Remédio Popular (Furp), de São Paulo, iniciaram a produção de antirretrovirais em 1999 e o Laboratório Farmacêutico do estado de Pernambuco (Lafep), em 2000. O início da produção nacional e as negociações com a indústria farmacêutica proporcionaram uma redução de $72,5 \%$ dos preços dos 
medicamentos antirretrovirais. Um comprimido de zalcitabina, que em 1996 custava 1,55 dólares passou a custar 0,08 dólares em 2000, produzida pelo Farmanguinhos. (FALCÃO, 2000)

Frente à política agressiva adotada pelo Brasil para a redução dos preços dos medicamentos para aids, em maio de 2000, os EUA abriram uma consulta na OMC junto ao governo brasileiro acerca do artigo $68 \mathrm{da}$ Lei 9.279/96 (Lei da Propriedade Industrial), que trata da licença compulsória de patentes, considerando que a mesma desrespeitava o acordo Agreement Trade-Related Aspects of Intellectual Property Rights (Trips). ${ }^{121}$ (WTO, 2000) Não satisfeitos com a resposta brasileira, os EUA entraram com uma queixa no Dispute Settlement Body ${ }^{122}$ (DSB) da OMC em janeiro de 2001 e chegaram a um acordo com o Brasil em 5 de junho de 2001, admitindo a possibilidade de quebra de patente em questões de saúde pública de países em desenvolvimento. (WTO, 2001a, 2001b)

A ação junto à OMC resultou de lobby da indústria farmacêutica norte-americana junto ao governo dos EUA em resposta ao congelamento de preços proposto pelo governo brasileiro, visando a redução de preços pelas indústrias detentoras das patentes, caso contrário seria usado o dispositivo da licença compulsória, prevista na Lei de propriedade industrial brasileira. (OLIVEIRA; MORENO, 2007) A solução foi a criação de um sistema de consultas bilateral: os EUA comprometeram-se a retirar a queixa, e o Brasil consultaria os EUA em caso de necessidade de uso do dispositivo da licença compulsória com relação a patentes de empresas daquele país. É interessante notar que, no acordo, os EUA pediam que o Brasil se comprometesse a não recorrer à OMC em relação às seções $204 \mathrm{e}$ 209 da Lei de patentes norte-americana, que se assemelhavam aos artigos 68 e 71 da Lei de Propriedade Industrial brasileira e que portanto tornavam sem efeito a queixa. (WTO, 2001a)

O recuo dos EUA constituiu-se importante vitória para o Brasil. Contudo, as discussões acerca da necessidade de revisão do acordo Trips

\footnotetext{
121 Acordo sobre os aspectos dos Direitos de Propriedade Intelectual relacionados ao comércio, entre os membros da OMC, que estabelecem padrões mínimos no âmbito do direito internacional relacionados às patentes, inclusive de medicamentos.

122 Órgão de Solução de Controvérsias.
} 
e da forma de lidar com as patentes nas questões de saúde pública, em especial para países em desenvolvimento, continuaram em fóruns multilaterais como a ONU.

Em 30 de outubro de 2001, foi realizada reunião entre o Unaids e parlamentares brasileiros em Brasília visando a criação de uma Frente Parlamentar de luta contra a aids, à qual se integraram os senadores Lúcio Alcântara (PSDB-CE) e Ricardo Santos (PSDB-ES), e os deputados Nelson Pellegrino (PT-BA), Fernando Gabeira (PT-RJ), Gilmar Machado (PT-MG), Esther Grossi (PT-RS), Laura Carneiro (PFL-RJ), Léo Alcântara (PSDB-CE), Maria Elvira (PMDB-MG), Marisa Serrano (PSDB-MS), Rita Camata (PMDB-ES), Marcos Rolim (PT-RS) e Agnelo Queiroz (PC do B-DF). (BRASIL, 2001a) O deputado Fernando Gabeira (PV-RJ) apresentou moção solicitando a solidariedade de todos os parlamentares do mundo à posição do Brasil de garantir medicamentos genéricos aos portadores de HIV. O pedido dava-se em razão da reunião da OMC no dia 9 de novembro, e da ameaça de países que queriam impedir a produção de genéricos no país. (BRANDÃO, 2001)

O Brasil estava liderando a negociação com a OMC desde setembro de 2001 para que o acordo Trips não fosse uma barreira para o acesso aos medicamentos e que estes fossem encarados como questão de Direitos Humanos. (UNAIDS, 2001) A Declaração sobre o acordo Trips e saúde pública foi assinada durante a Conferência Ministerial da OMC, entre $9 \mathrm{e}$ 14 de novembro de 2001, ${ }^{123} \mathrm{em}$ Doha, no Catar. (WTO, 2001c)

O resultado positivo sobre indicadores de morbi-mortalidade alcançado pela política de aids, com o acesso universal a medicamentos antirretrovirais, a partir de 1997, levou a um reconhecimento internacional da estratégia brasileira, com impacto importante sobre o financiamento internacional, que se deslocou para países com respostas menos estruturadas e quadro epidemiológico mais grave.

O Programa Nacional passou a assumir uma posição dominante no espaço aids nacional e a ser reconhecido no cenário internacional, todos os seus gestores permaneceram no espaço aids e assumiram posições

123 Para maiores esclarecimentos consultar Correa (2005). 
importantes em organismos internacionais, bem como diversos gestores municipais e/ou estaduais e técnicos do Ministério da Saúde, com maior destaque, assumiram posições no espaço aids internacional.

\section{Transformações no espaço aids: quem passou a se interessar pela aids e por quê?}

A resposta brasileira à epidemia da aids foi se tornando mais complexa ao longo dos 20 anos analisados no presente estudo. A estrutura do espaço aids brasileiro mostrou-se bastante dinâmica no referido período (19812001), com novos grupos de agentes sendo incorporados ao espaço militante a partir das mudanças observadas no comportamento epidemiológico da doença, assim como o estabelecimento de relações com agentes e instituições de outros espaços, como a indústria farmacêutica e organismos internacionais externos ao setor saúde como a Organização Mundial do Comércio, o que levou também a um maior envolvimento do campo político, com a criação da Frente Parlamentar de luta contra a aids em 2001.

Os entrevistados foram analisados de acordo com subespaço de pertencimento, volume de capital e sua relação inicial com o espaço aids também em 2001. (Quadro 10) Dos 33 entrevistados, 25 estavam no espaço aids em 2001, sendo 14 desde o período de 1983-1986. Dos 20 entrevistados que se inseriram no espaço até 1986 (Quadro 3), sete afastaram-se do espaço aids até 2001: E7, E8, E10, E11, E24, E29 e E31. Outros entrevistados, como E2 e E5, que entraram nesse espaço mais tarde, também se afastaram posteriormente. As saídas do espaço aids muito revelam de sua natureza de espaço de lutas e conflitos de ordem política, burocrática e geracional, envolvendo paixões (illusio). 
QUADRO 10 - Agentes participantes e fundadores do espaço aids segundo subespaço de pertencimento, graduação, profissão dos pais, volume de capital científico, burocrático, político e militante e relação com a aids, em 2001

\begin{tabular}{|c|c|c|c|c|c|c|c|c|c|}
\hline E & Graduação (ano) & SE & Prof. Pai & $\begin{array}{l}\text { Capital } \\
\text { cultural } \\
\text { (Escolar) }\end{array}$ & CC & CB & CP & CM & Relação com a aids ${ }^{1}$ \\
\hline 15 & Turismo (S/I) & \multirow{9}{*}{ 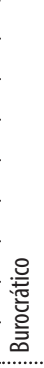 } & Policial civil & $S$ & - & $P$ & - & - & Profissional \\
\hline 30 & Medicina (1985) & & Contador & PGS & - & A & - & - & Profissional \\
\hline 17 & Sociologia (S/I) & & $S / I$ & PGL & - & A & B & - & Profissional \\
\hline 23 & Medicina (1989) & & Eletrotécnico & $S$ & - & A & - & - & Profissional \\
\hline 28 & Proc. De dados (S/I) & & Médico pediatra & PGL & - & A & - & - & Profissional \\
\hline 21 & Economia (após 2001) & & Marceneiro & $S$ & - & A & - & - & Profissional \\
\hline 1 & Ciências Sociais (1992) & & Empresário & PGL & - & A & - & - & Profissional \\
\hline 26 & Medicina (1973) & & Contador & PGL & - & $A A$ & - & B & Profissional \\
\hline 27 & Medicina (1977) & & Comerciante & $S$ & - & $A A$ & B & - & Profissional \\
\hline 28 & Hotelaria (1994) & \multirow{10}{*}{ 总 } & Agricultor & $S$ & - & - & - & $M$ & Pessoal \\
\hline 22 & Psicologia (1991) & & Representante lab. farm. & $S$ & - & - & - & M & Pessoal \\
\hline 5 & Ciências Sociais (1988) & & Militar & PGS & B & A & - & M & Profissional \\
\hline 33 & Psicologia (1985) & & Militar & PGS & B & - & B & $M$ & Pessoal \\
\hline 14 & Administração (após 2001) & & Comerciante & $E M$ & - & - & - & A & Pessoal \\
\hline 6 & Filosofia $(S / I)$ & & Político & 5 & - & - & - & A & Pessoal \\
\hline 12 & Administração (após 2001) & & Vendedor & EM & - & M & - & A & Pessoal \\
\hline 18 & Matemática (1972) & & Contador & PGS & M & - & B & A & Pessoal \\
\hline 20 & Ciências Sociais (1968) & & Fazendeiro & PGS & $M$ & - & B & A & Pessoal \\
\hline 3 & Direito (S/I) & & * & $S$ & - & - & B & A & $\begin{array}{l}\text { Profissional/ } \\
\text { Pessoal }\end{array}$ \\
\hline 19 & Medicina (1961) & \multirow{6}{*}{ 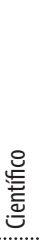 } & Comerciante & PGS & $B$ & A & B & - & Profissional \\
\hline 25 & Ciências sociais (1987) & & Comerciante & PGS & B & - & - & - & Pessoal \\
\hline 16 & Medicina (1981) & & Médico, professor & PGS & $M$ & $M$ & - & - & Profissional \\
\hline 32 & Psicologia (1977) & & Político & PGS & $M$ & - & - & $B$ & Profissional \\
\hline 4 & Medicina (1969) & & Professor & PGS & A & B & B & B & Profissional \\
\hline 9 & Medicina (1965) & & Telegrafista & PGS & $A A$ & A & - & - & Profissional \\
\hline
\end{tabular}

Fonte: Elaborado pela autora.

Notas:*Pai falecido quando a entrevistada tinha apenas 2 meses, avô paterno mascate, avô materno fabricante de vinhos. / CC: capital científico; CB: capital burocrático; CP: capital político; CM: capital militante; S/I: sem informação; S: superior; EM: ensino médio; PGS: pós-graduação strito senso; PGL: pós-graduação lato senso, B: baixo; M: médio; A: alto; AA: muito alto.

(1) O Apêndice Capresenta as falas dos entrevistados que resultaram na classificação apresentada no Quadro 13. 
O afastamento dos agentes do espaço aids esteve relacionado (Quadro 11):

- A motivos pessoais, como a perda de parentes e amigos, vítimas da epidemia, no caso de E8;

- A questões profissionais como:

- problemas de relacionamento (brigas, desentendimentos ou não adaptação a novas gestões) no trabalho, como nos casos de E7, E29,E23 e E5;

- incompatibilidade ou limitação do trabalho relacionado à aids em relação aos anseios profissionais, como nos casos de E2 e de E11, para os quais a aproximação com a aids ocorreu pela vinculação, respectivamente, à área de planejamento e com a Divisão Nacional de Dermatologia Sanitária. E2 não queria limitar a sua atuação a uma política de saúde específica e também pretendia ter sua inserção prioritária no campo científico. E11 tinha por opção profissional a dermatologia e o trabalho com hanseníase, com a separação das duas áreas, optou por atuar no Programa de Hanseníase, no qual chegou a ser dirigente do programa; e, até mesmo, o sucesso da política, como no caso de E31, também presente na fala de E11.

Os agentes do subespaço burocrático foram os que apresentaram menor capital cultural, geralmente, nível superior ou pós-graduação lato senso. A exceção foi a médica E30, que à época era coordenadora do Programa Estadual de DST/Aids do Estado do Rio de Janeiro, tendo assumido anteriormente a chefia da Unidade de Assistência do PN DST/ Aids entre 1997 e 2000. E30 desde 2006 assumiu a diretoria do Instituto de Pesquisa Clínica Evandro Chagas e em 2008 concluiu o doutorado em Saúde Pública, participando a partir de então do subespaço científico.

A relação com a aids no momento de engajamento no subespaço burocrático, deu-se, como no período de 1983-1986, por questões profissionais e os agentes concentravam principalmente, e quase exclusivamente, capital burocrático. Apenas E26, E27 e E17 apresentaram pequeno volume 


\begin{tabular}{|c|c|c|}
\hline Agente & $\begin{array}{l}\text { Subespaço no momento } \\
\text { do afastamento }\end{array}$ & Evidências \\
\hline E2 & Burocrático & $\begin{array}{l}\text { "[...] Eu me lembro de que uma vez alguém comentou comigo,'você que tem essa habilidade } \\
\text { no planejamento, você podia utilizar isso para ser uma consultora'e essa coisa de carreira } \\
\text { internacional, mas eu acho isso uma bobagem. Eu não tenho interesse, eu não tenho, nesse } \\
\text { sentido não [...] eu não teria vontade de trabalhar com uma política mais específica assim na } \\
\text { minha vida profissional." }\end{array}$ \\
\hline E5 & Burocrático & $\begin{array}{l}\text { "[...] eu queria sair daquele ritmo enlouquecido que eu estava no Ministério ainda que eu } \\
\text { pudesse fazer consultorias para o Ministério mais pontuais, [...] E depois realmente o ritmo } \\
\text { do trabalho mudou, [...] Então a ONG aqui de São Paulo acha que o projeto dela não está bom } \\
\text { não sei porquê, mandava e-mail para o XXXX, o XXXX respondia, a ONG do Rio mandava para o } \\
\text { XXXX, o XXXX respondia, então a chefe da unidade não serve para nada, porque eles resolvem } \\
\text { do jeito que querem depois você fica sem saber, [...] ele nem se tocava que eles passavam por } \\
\text { cima. XXXX nunca fez isso. Chegava uma correspondência para ele reclamando de tal projeto, } \\
\text { ele respondia com copia para mim - estou encaminhando para a chefe da unidade - então, } \\
\text { isso te empodera, porque diz a autoridade que você tem [...]." }\end{array}$ \\
\hline E7 & Burocrático & $\begin{array}{l}\text { "[...] hoje eu nem sei mais quase nada de aids, desencantei, sai daquela coisa, que é uma } \\
\text { politicagem que eu não aguentei. Não faz bem pra minha saúde mental. Agora, não, agora que } \\
\text { virou doença de pobre, né? Mas na época, era muito virulento... Nossa! [...] foi uma decisão } \\
\text { minha, mas eles começaram a me boicotar. [...] eles foram me solapando e ai eu dei uma } \\
\text { entrevista que a campanha do carnaval não saiu porque não autorizaram a tempo [...] aí ele me } \\
\text { chamou lá, me tirou, disse que iam trazer XXXX de volta porque fazia parte lá do grupo dele. } \\
\text { Porque XXXX, ele tinha muitas conexões entre os sanitaristas brasileiros, um monte de coisa } \\
\text { lá. [...] Eu ainda fiz algumas coisas, tentei algumas coisas, mas ai tudo que eu fosse tentar, } \\
\text { eu ia ser podado, [...] fui aos poucos mudando. Não é fácil não. [...] eu me interesso até hoje, } \\
\text { eu tenho uma visão... acompanho um pouco, mas ai, profissionalmente, você começa a fazer } \\
\text { pesquisa em outras áreas, aí você começa a ser absorvido." }\end{array}$ \\
\hline E8 & Militante & $\begin{array}{l}\text { "Daí, o meu irmão teve aids. E morreu. E sabe, eu lá, militante, uma das pessoas que mais falava } \\
\text { sobre o assunto, não sei o que, eu não soube reconhecer quando ele estava com aids. [...] Daí } \\
\text { fiquei completamente desgostoso com o tema, com as pessoas, comigo mesmo, com tudo. [...] } \\
\text { e não quis mais lidar muito com esse tema de homossexualidade, o tema da aids. E aí eu já } \\
\text { estava desgostoso com essa briga do Somos e todas essas coisas." }\end{array}$ \\
\hline E11 & Burocrático & $\begin{array}{l}\text { "[...] } 0 \text { Programa de Aids foi para um canto e o programa de hanseníase ficou em outro canto. } \\
\text { E aí nessa divisão foi que eu sai do Programa de Aids. Eu preferi, porque eu sou dermatologista } \\
\text { e minha formação é em hanseníase, e aí eu fiquei na hanseníase. E aí só voltei para a aids no } \\
\text { ano de 2004." }\end{array}$ \\
\hline E23 & Burocrático & $\begin{array}{l}\text { "[...] foi uma forma de proteção pra mim. Se eu continuasse vivendo, acompanhando o } 0 \\
\text { movimento, eu ia sofrer. Então eu preferi realmente apagar, é página virada, apagada do meu } \\
\text { folhetim.." }\end{array}$ \\
\hline E29 & Militante & $\begin{array}{l}\text { "Eu já queria sair, eu sentia que já tinha cumprido um ciclo, mas a saída em si foi meio } \\
\text { traumática, porque houve uma briga lá, não foi muito boa..." }\end{array}$ \\
\hline E31 & Científico & $\begin{array}{l}\text { "Eu me retirei por uma razão só [...] Porque eu acho que funciona muito bem no sistema. } \\
\text { Porque você tem jovenzinhos nos postos de saúde que são muito mais bem informados do que } \\
\text { eu, que vão aos congressos animadamente, que acompanham tudo, que eu não tenho mais } \\
\text { paciência para acompanhar. Que disputam espaços e tudo isso e eles fazem isso com muito } \\
\text { mais habilidade. [...]" }\end{array}$ \\
\hline
\end{tabular}

Fonte: Elaborado pela autora.

Nota: XXXX - supressão de nomes de indivíduos citados. 
de capital militante e político, respectivamente. Os demais agentes do subespaço burocrático não possuíam qualquer engajamento político ou militante. É interessante notar, contudo, que diversos dos agentes desse subespaço gozam de grande reconhecimento (capital simbólico) ao interior dos diferentes subespaços do espaço aids, como E26 e E27, por exemplo. (Quadro 10) Talvez a possessão de um capital (burocrático) garantido pelo Estado, que corresponde a um meta capital, lhes tenha garantido poder sobre outros tipos de capital, ou seja, para além do capital garantido pelos títulos ou diplomas, os agentes do Estado possuem o poder de nomeação, delegado pelo Estado, quer dizer, possuem um capital que dá poder sobre outras espécies de capital e, portanto, sobre outros campos no sentido de Bourdieu (2012). Por exemplo, o Programa Nacional, define quem são os experts nacionais em medicamentos antirretrovirais, quando indica ou nomeia quem vai participar do comitê específico para esse fim.

O subespaço militante continuou atraindo principalmente agentes que tinham uma relação pessoal com a aids - pessoas vivendo com HIV/ aids, grupos com maior risco para adquirir a doença, amigos e familiares. Entre os que ingressaram após 1986, apenas E5 teve uma aproximação profissional. Os novos agentes possuíam, em 2001, menor capital cultural que aquele apresentado pelos militantes que ingressaram no espaço aids no período entre 1983-1986: se os mais antigos possuíam, quase todos, pós-graduação (mestrado ou doutorado), a única exceção era a advogada E3, entre os seis mais novos predominava curso superior completo (50\%), seguido do ensino médio (33,3\%), apenas um (1,7\%) agente possuindo pós-graduação (doutorado). Entre os militantes, E5 e E12 possuíam um volume alto e médio, respectivamente, de capital burocrático. Em 2001, E5 assumiu a Unidade de Articulação com a Sociedade Civil e Direitos Humanos do PN de DST/Aids, de 1992, até aquele momento seu engajamento era no espaço militante. (Quadro 10) Contudo, após a sua inserção no Ministério da Saúde, não considerava o retorno à(ao) militância/ativismo uma opção.

[...] apesar do tempo que eu fiquei no programa e de eu achar que conseguia esse distanciamento com o movimento, principalmente com o Pela Vidda, [...] mas 
quando eu saí do programa eu tinha certeza que eu não queria voltar para ONG, para mim não tinha nada a ver profissionalmente, por outro lado o fato de eu ter sido do governo também não me deixou à vontade no primeiro momento que eu fosse virar ativista de novo, no sentido pleno do termo [... ]. (E5 $)^{124}$

E12 também teve uma experiência na gestão, na Secretaria Municipal de Porto Alegre e inclusive defende que os gestores da política de HIV/ aids deveriam ser pessoas vivendo com HIV/aids.

[...] isso faz o diferencial. Na medida que eu estou aqui trabalhando, eu sei que nesse exato momento tem um monte de gente no hospital de clínicas, na emergência, com infecção oportunista, com diagnóstico tardio. O problema é que eu fico pensando isso todo o tempo. Eu não enxergo isso como um problema do outro apenas. Eu enxergo isso como um problema de quem vive com isso e quem pode a qualquer momento estar lá junto. Então eu sei da emergência disso. Eu sei muito mais da emergência disso, como uma mulher que na saúde da mulher sabe a emergência da questão da discussão do aborto. Para um homem pode até passar batido, mas para uma mulher essa discussão éfundamental. (E12)

Esse é um ponto de vista relacionado às disputas entre soropositivos e outros militantes no momento de criação da rede de pessoas vivendo com HIV/aids e mesmo anterior a esse período, quando foram criadas as primeiras ONGs de pessoas vivendo com HIV/aids.

[...] teve uma briga muito grande exatamente assim dessa coisa das ONGs que não representavam os soropositivos e que faziam dos soropositivos a estrada do assistencialismo absoluto. Então as pessoas ia lá só para receber e não participavam das decisões e nem da constituição. Então teve uma briga de um grupo de pessoas que viviam com HIV/aids com as instituições que estavam constituídas, exatamente para discussão de qual é o espaço de quem e o que fazemos aqui. Eu acho que isso era anterior até a constituição da rede e essa discussão ela foi se ampliando. Quando entrei para o movimento, logo na sequência, teve um encontro nacional em São Paulo e essa discussão ali se aprofundou, da 'ONG, que bicho é esse?', que

Entrevista concedida por E5, socióloga, diretora do Grupo Pela Vidda-RJ, em São Paulo, em 4 de maio de 2011. 
era o lema, então começou uma discussão muito forte exatamente para ver qual o lugar que esse soropositivo iria ocupar, e qual era a legitimidade das ONGs que estavam atéali instituídas. A princípio a rede acho que ela foi formada exatamente para poder ter o protagonismo de quem vivia com HIV/aids, de uma forma diferenciada. Houve uma ruptura entre essas pessoas e as ONGs mesmo que nessas outras ONGs tivessem pessoas soropositivas. O Gapa São Paulo é um exemplo disso. Paulo Bonfim que era o presidente, era pessoa vivendo com HIV/aids, mas a forma de trabalho nas ONGS é que estava sendo questionada. (E6)

Apenas dois dos entrevistados (E25 e E16) foram agentes do subespaço científico que entraram depois de 1986 no espaço aids. E25 iniciou sua relação com o espaço aids a partir de questões profissionais e E16 como objeto de pesquisa de sua dissertação de mestrado. Os agentes desse subespaço, em 2001, foram os que apresentaram uma maior diversidade de capitais. E4 possuía alto capital científico e pequeno volume de capital burocrático, político e militante, sendo o único agente que apresentava todos os tipos de capital estudados. A principal combinação foi o acúmulo de capital científico, específico do subespaço em questão, e capital burocrático, resultado da participação desses agentes (E19, E16, E4 e E9) em posições nas Secretarias Estaduais ou no Ministério da Saúde, em funções relacionadas ou não à aids, ou na burocracia universitária, em alguns momentos, ou de institutos de pesquisa/laboratórios. (Quadro 10)

Foi bastante frequente o trânsito de agentes do subespaço militante para o subespaço burocrático. Os militantes entrevistados que chegaram ao campo burocrático, em sua maioria, engajaram-se no espaço aids por motivo pessoal e referiram que essa era uma posição em que eles poderiam atuar de forma mais concreta, fazer mais, ir além da crítica política, o que na opinião de alguns inclusive tornava a sua atuação nesse subespaço ainda mais gratificante, como fica claro na fala de um dos entrevistados:

Você se sente realizado por ter militado na área de aids?

- Com certeza.

E trabalhando com aids? 
- Mais ainda. [...] Porque na militância, tu provoca, tu provoca, mas tu não faz.

Aqui eu posso fazer. (E12)

Entrevistados como E6 e E13 ainda não estavam no subespaço burocrático em 2001, mas quando foram entrevistados compunham o quadro do Departamento Nacional de DST/Aids e Hepatites Virais.

O mais frequente na história do programa/departamento sempre foi que um médico ocupasse a direção. As únicas exceções foram a sua primeira gestora, que era biomédica, e entre 2003 e 2004 o sociólogo Alexandre Grangeiro. Todos os outros gestores eram médicos: Pedro Chequer, Paulo Roberto Teixeira, Mariângela Simão, Dirceu Greco e Fábio Mesquita. O campo médico exerceu, e ainda exerce, papel dominante no espaço de forma que uma entrevistada chegou a afirmar que ser médico era um dos critérios para assumir a direção do programa/departamento.

Depois de participar da gestão da política e vivenciar os limites e possibilidades da gestão, de ter se tornado um agente do Estado, geralmente os militantes permaneciam no subespaço burocrático, faziam uma trajetória ao interior desse subespaço nos diferentes níveis de gestão do SUS, sendo contratados através de projetos viabilizados pelos acordos de empréstimo ou assumindo cargos de confiança, tornando-se o que Goulart (2006) denominou de "executivos da saúde". Contudo, devese destacar que há exemplos de agentes do espaço militante que, mesmo tendo assumido funções no campo burocrático, depois retornaram a esse espaço, como, por exemplo, Paulo Bonfim do Gapa que assumiu a coordenação do Programa Municipal de DST/Aids de São Paulo entre 1989 e 1991, e no retorno ao Gapa, assumiu a presidência da entidade (ABBADE; BAIÃO, 2010), o que pode ser explicado pela diversidade de trajetórias dos agentes analisados. Ao assumirem posições na gestão da política de aids, esses agentes adotaram uma postura empreendedora, buscando promover inovações, principalmente devido ao seu envolvimento emocional com a causa em questão, congregando dedicação, criatividade e iniciativa à sua atuação, o que caracterizaria o empreendedorismo militante. (GOULART, 2002) Esses agentes fizeram uma conversão do seu capital militante em burocrático, adaptando para o campo burocrático o 
conjunto de saberes e práticas adquiridos nas mobilizações, nas lutas e na atuação no movimento associativo sob a forma de técnicas, de disposições de agir, intervir ou simplesmente obedecer.

Outro aspecto importante referido por todos os entrevistados é a satisfação de ter participado da construção da resposta brasileira à epidemia da aids. Quando questionados acerca da realização profissional, alguns referiram que preferiam não se sentir realizados, para continuar indignando-se, mas de uma forma geral, aparecem sentimentos como engajamento e orgulho de ter contribuído para a elaboração de uma política reconhecida internacionalmente pelos seus resultados, ainda que esteja presente nas falas também a necessidade de continuar lutando pela manutenção e sustentabilidade das conquistas. (APÊNDICE I) Alguns agentes do subespaço científico (E9, E19, E30) também transitaram pelo espaço burocrático, mas esses ou não se desvincularam em nenhum momento de seu espaço de origem, atuando em dois subespaços (científico ou burocrático), ou retornaram ao seu espaço de origem após um período na gestão.

No campo burocrático, predominaram os médicos desde o início da configuração do espaço, em especial os dermatologistas sanitários e médicos sanitaristas. Alguns clínicos docentes de escolas médicas de renome e referências nacionais na área das doenças ditas "tropicais", como Ricardo Veronesi e Vicente Amato Neto, contribuíram para a elaboração do discurso oficial, participando de reuniões e da Cnaids. Eduardo Côrtes foi o único médico clínico a assumir a direção do programa no período analisado, mas a participação de médicos clínicos no campo burocrático aumentou à medida que foram surgindo possibilidades terapêuticas. Essa participação tornou-se mais evidente principalmente a partir da descoberta do coquetel, na maioria das vezes através da participação em comissões e comitês específicos. Progressivamente o quadro técnico do programa incorporou agentes com diferentes formações, inclusive com a contratação do pessoal oriundo dos movimentos sociais, aumentando significativamente o número de funcionários desde a sua criação até os dias de hoje, já sendo o Departamento de DST, Aids e hepatites virais, desde 2009, o departamento contava, em 2011, com aproximadamente 240 funcionários. 